\title{
O GESTOR E A PCD: REFLEXÕES SOBRE APRENDIZAGENS E COMPETÊNCIAS NA CONSTRUÇÃO DA DIVERSIDADE NAS ORGANIZAÇÕES
}

\author{
Claudia Serrano \\ claudia@arquiteturarh.com.br \\ Universidade Presbiteriana Mackenzie - SP/Brasil \\ Janette Brunstein \\ janette@mackenzie.br \\ Universidade Presbiteriana Mackenzie - SP/Brasil
}

Recebido em 27/11/2008

Aprovado em 26/04/2011

Disponibilizado em 01/08/2011

Avaliado pelo sistema double blind review

Revista Eletrônica de Administração

Editor: Luís Felipe Nascimento

ISSN 1413-2311 (versão on-line)

Editada pela Escola de Administração da Universidade Federal do Rio Grande do Sul.

Periodicidade: Quadrimestral

Sistema requerido: Adobe Acrobat Reader.

\section{INTRODUÇÃO}

$\mathrm{O}$ gestor que recebe uma pessoa com deficiência $(\mathrm{PcD})$ em sua equipe de trabalho enfrenta um novo desafio: desenvolver competências que lhes permitam administrar com sucesso a inclusão, uma vez que a prescrição dos manuais corporativos ou institucionais não garantem, por si, o desenvolvimento das capacidades necessárias para ser bem sucedido como agente do processo inclusivo. Está é a temática central deste texto.

Graças ao aumento dos movimentos de pressão para a inclusão de grupos historicamente excluídos das posições de poder e prestígio, como deficientes, afro-descentes, homossexuais, políticas e práticas organizacionais em prol da diversidade se institucionalizam. Esse cenário implica em mudanças na maneira de pensar e agir da organização, tradicionalmente estruturada e conduzida pela lógica masculina, branca e heterossexual. Resta saber, porém, se, de fato, alterações significativas estão em curso.

Dado que diversidade se refere à busca de oportunidades iguais e respeito à dignidade de todos, princípio de cidadania, tem-se que as organizações e, mais especificamente, os gestores, tem de assegurar às PcDs, condições para desenvolverem plenamente seus talentos e potencialidades. A capacidade de lidar com desafios desta natureza instiga o debate sobre o 
desenvolvimento de competências que até pouco tempo não estavam no rol de preocupações das lideranças, nem dos responsáveis pelos programas de formação dos gestores.

Frente ao exposto, este estudo teve como principal objetivo analisar a experiência de gestores na inclusão de PcDs em suas equipes. A intenção foi descobrir qual o significado esses profissionais atribuem ao termo inclusão e de que forma ele vem se traduzindo em práticas inclusivas a partir da relação gestor/PcD. Pretendeu-se, com isto, identificar os processos de aprendizagem decorrentes da experiência da inclusão e as competências desenvolvidas pelos gestores ao tratar com o universo da PcD.

Seguindo a perspectiva das abordagens interpretativistas dos estudos em competência, a análise das experiências e a busca pelo significado atribuído pelos gestores ao ato de incluir foram fundamentadas no conceito de Sandberg (2000), para quem a competência, mais do que um conjunto de atributos, se constitui pelo significado que o trabalho assume para o trabalhador. Além disso, dada a complexidade que constitui a competência de incluir, adotouse o modelo holístico de Cheetham e Chivers (1996, 2005) como referência, já que incorpora aspectos éticos/valores como dimensões de competência.

A dificuldade de inserção das PcDs e a falta de preparo do mundo corporativo para absorver este profissional e fazê-lo progredir na empresa se traduzem em comportamentos que vão desde a segregação até a falta de reconhecimento de sua capacidade laborativa. Pretende-se, assim, contribuir para a reflexão sobre o desenvolvimento de competências com foco em um dos principais agentes do processo inclusivo na organização: o gestor.

\section{A inclusão e suas implicações para a gestão}

À medida que a interação entre grupos diferentes se torna mais frequente na organização, maior deve ser a habilidade comunicativa e de negociação frente à potencial ocorrência de conflitos e desentendimentos, o que deve ser observado pelas práticas de gestão (DAVEL e VERGARA, 2001). Assim, um modelo de gestão da diversidade que traga benefícios implica em administrar as relações de trabalho, a composição da força de trabalho e o emprego (COX, 1991). Além disso, também se faz necessário observar o o grau de pressão para incorporar grupos sociais excluídos das posições de poder e prestígio, bem como avaliar as atitudes dos gestores em relação a esses grupos sociais e como a empresa prioriza e responde estrategicamente às necessidades de uma força de trabalho diversa (DASS e PARKER, 1999). 
A presente pesquisa considera a perspectiva de aprendizagem como o processo base para promover e gerenciar a diversidade de forma dinâmica e estratégica no médio e longo prazo, ressaltando-se o papel do gestor neste processo.

Como bem colocam Thomas e Ely (1996), medidas devem ser tomadas para facilitar o aproveitamento das diferenças entre grupos a serviço da organização, seu crescimento e renovação, dentre elas: a) as lideranças devem reconhecer que, com a diversidade, existirá mais de uma maneira de se obter resultados positivos; b) a liderança deve reconhecer que perspectivas diferentes representam desafios e oportunidades de aprendizado; c) a cultura organizacional deve criar expectativas de alto padrão para todos, sem diferenciações; d) a cultura organizacional deve estimular o desenvolvimento pessoal; e) a cultura organizacional deve encorajar os debates e controvérsias e dar suporte aos conflitos construtivos; f) a cultura deve fazer os trabalhadores se sentirem valorizados; g) a organização deve ter uma missão articulada e amplamente divulgada; h) a organização deve ter uma estrutura relativamente igualitária e não-burocrática.

Como se pode perceber, gerenciar a diversidade é muito mais que criar equidade de emprego como resposta a uma ação afirmativa, tampouco se limita ao desenvolvimento de sistemas e procedimentos de gestão com impacto em todos os processos, como recrutamento e seleção, treinamento e desenvolvimento, acompanhamento de desempenho, promoções e desligamento de pessoal. O desenvolvimento da gerência para capacitá-los a lidar com a diversidade também deve ser privilegiado (HUMAN, 1996).

Os discursos gerenciais e as políticas de pessoal, embora reconheçam como uma realidade, quase sempre não sabem como lidar com a diversidade das pessoas e, não raramente, desenvolvem mecanismos extremamente poderosos de controle em prol da uniformidade, traço do modelo burocrático que parece mostrar-se impróprio quando o contexto demanda criatividade, inovação e capacidade de aprendizagem (BASTOS, 2001, p. 111)

Os gerentes necessitam ter consciência das diferenças, comunicar e mostrar respeito por elas, evitar estereótipos, inspirar e mobilizar pessoas (APPELBAUM; SHAPIRO; ELBAZ,1998). Para isso, é preciso estimular um processo de aprendizagem permanente, que questione com frequência as práticas rotineiras, propondo uma experimentação contínua e desafiando respostas prontas e suas premissas (ARGYRIS, 1999). Inclusão e o desenvolvimento de competência para tanto é um fenômeno sociamente construído.

Incluir implica aprender a lidar com a heterogeneidade e na desmitificação das idéias errôneas sobre a deficiência, isto é dar-lhe um novo significado. E isso representa um incomensurável desafio, que envolve descartar o significado pejorativo associado à questão da deficiência. Significa abrir mão dos mecanismos de defesa, de conhecer e refletir sobre a 
parcela de construção social que perpetua os preconceitos, esteriótipos e estigmas em relação à deficiência (AMARAL, 1995). Nas organizações significa não só incorporar a PcD ao quadro funcional, mas também criar condições para seu desenvolvimento profissional e progressão na carreira. $\mathrm{O}$ estudo ora apresentado apóia-se nestas idéias.

No Brasil, os estudos revelam ausência de uma política específica para as PcDs (HEINSKI, 2004) e, por consequência, o que se observa nas organizações são práticas ingênuas que pouco contribuem para o avanço da inclusão (DOVAL; HARO, 2006). Além disso, embora as razões para não contratar tenham diminuído e a procura por essa mão-deobra tenha aumentado, as contratações são motivadas mais pelo interesse por parte do meio empresarial em realizar um trabalho social (BATISTA, 2003). Outra situação crítica observada por Heinski (2004) é que a maioria das PcDs contratadas têm deficiências leves.

A gestão inclusiva requer mais do que a elaboração e implementação de normas e procedimentos: requer mudanças culturais, e o gestor, sendo legítimo representante e agente de manutenção da cultura organizacional, precisa desenvolver não apenas a consciência, mas, também, competências para responder a desafios e oportunidades impostos pela diversidade.

\section{Competências para a inclusão no contexto da diversidade nas organizações}

O ingresso recente e mandatário das PcDs nas organizações, as especificidades da inclusão representada pelo tipo e grau de deficiência, somados ao isolamento social em que vivem os deficientes em nossa sociedade fazem com que o desafio dos gestores quanto à inclusão de PcDs na organização passe, necessariamente, por um processo de aprendizagem centrado na experiência e pelo desenvolvimento de novas competências.

Parte este estudo do pressuposto de que não é possível desenvolver um modelo único de inclusão que contemple toda a complexidade desse processo. Sendo assim, a reflexão e a ação são dois atributos imprescindíveis para que se faça uma inclusão competente. Vale ressaltar aqui o modelo de aprendizagem no local de trabalho apresentado por Raelin (1997), para quem esta se efetiva quando as pessoas trabalham problemas em tempo real no ambiente profissional. O gestor somente poderá dar conta dessa tarefa complexa se estiver preparado para atuar com autonomia, responsabilidade e puder desenvolver saberes para agir com pertinência frente ao desafio de incluir (ZARIFIAN, 2001; LE BOTERF, 2003).

Tendo em vista que a inclusão de PcDs na organização se insere no contexto dos estudos de diversidade, cabe considerar, também, a definição apresentada por Cox e Baele (1997), que defendem que alcançar tal capacidade de ação pressupõe o desenvolvimento do que chamaram de competências para a diversidade. A diversidade é tratada aqui como contexto, o 
que significa que se está interessado na mobilização pelo gestor de diversas competências que o habilitem a dar respostas para as situações de diversidade. Pensar em competências para a diversidade não implica, assim, estabelecer uma lista prescritiva de competências nem a necessidade de criar novas categorias de competência, mas, sim, identificar quais conhecimentos e habilidades são mobilizados pelos gestores para tratar das questões relacionadas às diferenças presentes no contexto no qual atuam. Dito isto, o termo 'competências em diversidade' será mantido para se fazer referência ao tratamento dado pelos autores Cox e Baele (1997).

Para Cox e Baele (1997), as três fases do desenvolvimento de competências para a diversidade envolvem: consciência, conhecimento e ação. Isso equivale dizer que o processo de aprendizagem que leva ao desenvolvimento das competências em diversidade acontece no dia-a-dia do ambiente de trabalho. Os sujeitos que aprendem o fazem por meio das interações sociais, no ambiente cultural em que estão (GHERARDI et al., 1998). Vale aqui ressaltar que, mesmo que as três fases apresentadas pelos autores sejam aplicáveis a qualquer processo de desenvolvimento, as relações que estabelecem entre estas fases e os desafios da diversidade se traduzem em um esquema teórico de análise pertinente para o tema.

Os gestores são os atores e autores de seu processo de desenvolvimento (LEITE; GODOY; ANTONELLO, 2006). O desenvolvimento de competências em diversidade tem de permitir que lidem de maneira saudável com a tensão gerada pela inclusão por meio de ações que representem valor agregado àquele que inclui e que é incluído.

A proposta de Sandberg (2000) representa uma contribuição de valor nas discussões sobre competência. Ao se valer da análise fenomenológica para entender as variações qualitativas das experiências individuais, contribui ao apontar a fragilidade dos estudos fundamentados no racionalismo, sobretudo o modelo norte-americano. Demonstra que a competência humana não é apenas um conjunto específico de atributos, mas emerge da estrutura básica de significados construída a partir das concepções dos trabalhadores sobre seu trabalho, estrutura esta desenvolvida em função do modo específico como esse trabalho é compreendido pelos sujeitos. Os indivíduos atuam mediados por suas experiências, em um processo de consciência prática (SANDBERG, 2000).

Essa compreensão do significado do trabalho é apontada por Sandberg (2000) como a primeira fase para a definição de competências. A concepção sobre o trabalho orienta não apenas a forma como este é realizado, mas também quais atributos estão sendo mobilizados para sua realização, o que equivale a dizer que apreender os aspectos essenciais da competência consistiria em adotar a interpretação do trabalhador sobre o trabalho. Este é o 
ponto no qual esta pesquisa se fundamenta: entender qual o significado que os gestores dão ao ato de incluir e como esse significado se traduz em ações inclusivas.

Zarifian (2001) reconhece que cada indivíduo pode dar um sentido particular a seu trabalho em função da relação que o mesmo estabelece entre suas ações e o sistema de valores que orientam esses atos. Se os valores guiam a conduta dos indivíduos, trata-se de observá-los no processo de desenvolvimento de competências para a inclusão. A importância dos valores também é identificada na pesquisa desenvolvida por Cheetham e Chivers (1996, 2005), na qual apresentam um modelo holístico de competências. Segundo os autores, ética e valores são componentes fundamentais para o desempenho profissional eficaz, uma vez que direcionam todas as atividades e definem decisões e ações.

Cheetham e Chivers $(1996,2005)$ reputam como fundamental a contribuição dos julgamentos éticos para o desempenho profissional. Desta forma, seu modelo holístico é formado por cinco conjuntos de competências inter-relacionadas: a) cognitivas: posse do conhecimento apropriado relativo ao trabalho e à habilidade de mobilizar esse conhecimento; b) funcionais: habilidade para executar tarefas de maneira a produzir resultados específicos; c) comportamentais: habilidade de adotar comportamentos apropriados, observáveis em situações relativas ao trabalho; d) valores/éticas: posse de valores pessoais e profissionais apropriados e habilidade para realizar julgamentos sensatos - referem-se à aplicação efetiva e apropriada de valores em contextos profissionais; e e) meta-competências: competências que ajudam a desenvolver outras competências ou aumentar e mediar qualquer outra competência dos demais componentes. 
Claudia Serrano \& Janette Brunstein

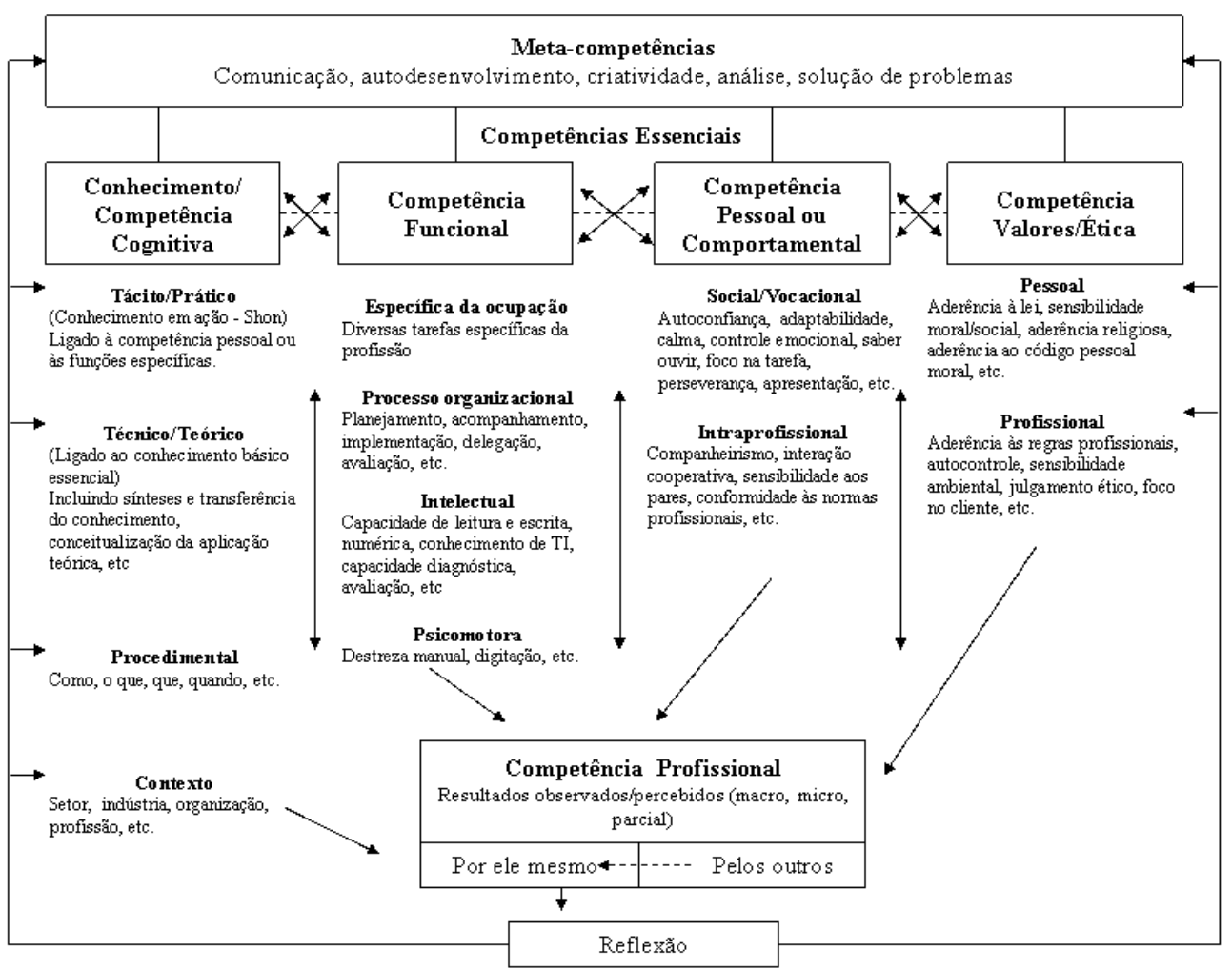

Figura 1 - Modelo holístico de competências

Fonte: Cheetham e Chivers (1996, p. 27)

Um aspecto apontado por Cheetham e Chivers (1996) se relaciona ao fato de que os resultados das ações cotidianas devem levar o profissional à reflexão, a pensar sobre o processo que o conduziu a esse desempenho e desenhar estratégias de melhoria.

Embora não exista um consenso sobre considerar valores/ética como competências, este estudo não pretende polemizar tal questão. Sendo assim, adotou-se o modelo original de Cheetham e Chivers (1996, 2005), considerando valores e ética como dimensões de competência. Em síntese, a análise a que se propõe este trabalho parte da identificação do significado do ato de incluir pelos gestores tendo por referência o modelo de Sandberg (2000); e as dimensões da competência de incluir a partir dos elementos apresentados por Cheetham e Chivers (1996, 2005), com destaque para os processos de aprendizagem na construção da competência para a diversidade do modelo de Cox e Baele (1997).

Tendo estabelecido as bases teóricas e conceituais, passa-se agora à apresentação dos procedimentos de pesquisa, seguida de análise e interpretação dos resultados.

\section{Procedimentos de investigação e análise}


Coerente com o paradigma interpretativo (GEPHART, 2004), a orientação metodológica seguiu a proposta do estudo qualitativo interpretativo básico ou genérico de Merriam (1998, 2002) e Caelli e Ray e Mill, (2003). Concentra-se este tipo de estudo na perspectiva e visão de mundo das pessoas envolvidas no contexto investigado e os diferentes significados atribuídos pelos gestores e PcDs que participam do processo de inclusão, de maneira a entender quais competências são necessárias para realizar esse processo, bem como de que maneira essas capacidades são desenvolvidas e traduzidas em práticas inclusivas.

Os dados foram coletados durante todo o ano de 2007, em cinco empresas multinacionais distintas, dos segmentos: agronegócios, automotivo, editorial, energia e tecnologia diesel. O principal instrumento de coleta de dados foi entrevistas em profundidade, semiestruturadas, realizadas (i) com gestores que possuem PcDs em suas equipes há pelo menos um ano; e (ii) com as PcDs a eles subordinadas, com deficiências moderadas a severas, de maneira a permitir a análise de situações específicas de inclusão que não ocorreriam no caso da deficiência leve. As entrevistas foram realizadas nas dependências das empresas.

O tratamento dos dados coletados foi conduzido seguindo a proposta de interpretação do conteúdo da informação textual de Gil Flores (1994). Para analisar, interpretar e categorizar as informações obtidas, os dados apreendidos por meio das entrevistas em profundidade foram exaustivamente manipulados na busca de padrões, coerências e núcleos centrais de significados. O processo de categorização foi conduzido a posteriori. Definiram-se, assim, quatro conjuntos de categorias centrais (metacategorias) e seus elementos pertinentes, buscando, ao final, entender de que forma estas se inter-relacionam: significado de inclusão, relações interpessoais, processo de aprendizagem e competências para a inclusão.

Dentre as metacategorias, foram identificadas nove subcategorias: significado de inclusão; sentimento de inclusão/exclusão; as relações entre o gestor e a PcD; relações entre a $\mathrm{PcD}$ e a equipe de trabalho; formas de aprendizagem; processo de aprendizagem, consequências da aprendizagem; papel do gestor; e competências necessárias e desenvolvidas.

O quadro a seguir sintetiza o perfil dos entrevistados.

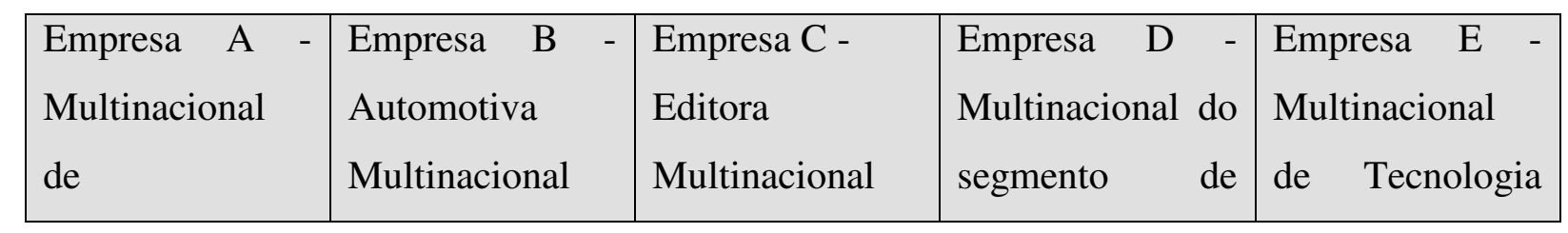


Claudia Serrano \& Janette Brunstein

\begin{tabular}{|c|c|c|c|c|}
\hline Agronegócios & & & Energia & Diesel \\
\hline $\begin{array}{l}\text { Gestor } 1-\text { IT } \\
\text { Manager } \\
\text { Formação em } \\
\text { Ciências } \\
\text { Contábeis, } 47 \\
\text { anos. } \\
\text { Supervisiona } 1 \\
\text { PcD há } 3 \text { anos. } \\
\text { Gestor } 2 \text { - IT } \\
\text { Cordinator } \\
\text { Formação em } \\
\text { Análise de } \\
\text { Sistemas, } 30 \\
\text { anos. } \\
\text { Supervisiona } 1 \\
\text { PcD há } 3 \text { anos. }\end{array}$ & 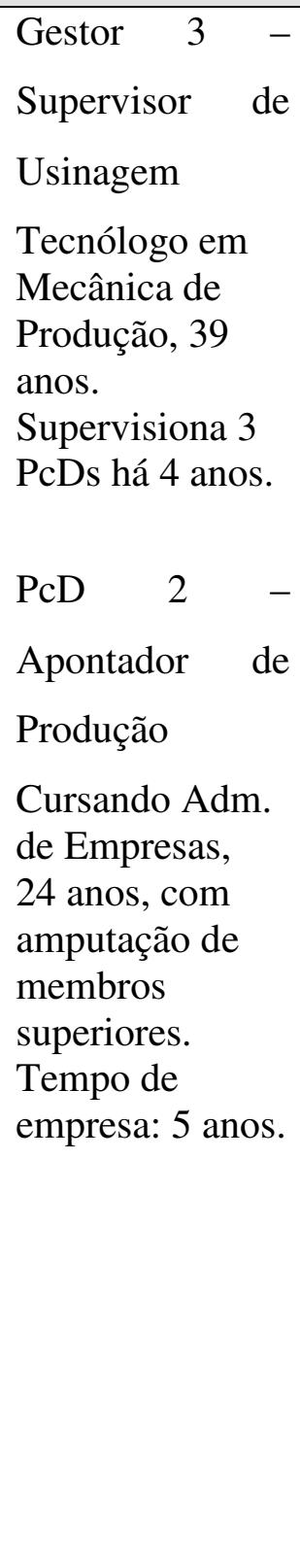 & $\begin{array}{l}\text { Gestor } 4 \\
\text { Gerente de } \\
\text { Atendimento } \\
\text { Adm. de } \\
\text { Empresas, } 39 \\
\text { anos. } \\
\text { Supervisiona } 12 \\
\text { PcDs há } 2 \text { anos. } \\
\text { PcD } 3 \\
\text { Assistente } \\
\text { Atendimento } \\
\text { Ensino médio, } \\
\text { 33 anos, com } \\
\text { paraplegia de } \\
\text { membros } \\
\text { inferiores. } \\
\text { Tempo de } \\
\text { empresa: } 5 \text { anos. }\end{array}$ & $\begin{array}{l}\text { Gestor } 5 \\
\text { Analista } \\
\text { Administrativo } \\
\text { Pl. } \\
\text { Pedagoga, com } \\
\text { pós em } \\
\text { Administração, } \\
48 \text { anos. } \\
\text { Supervisiona } 10 \\
\text { PcDs há } 3 \text { anos. }\end{array}$ & 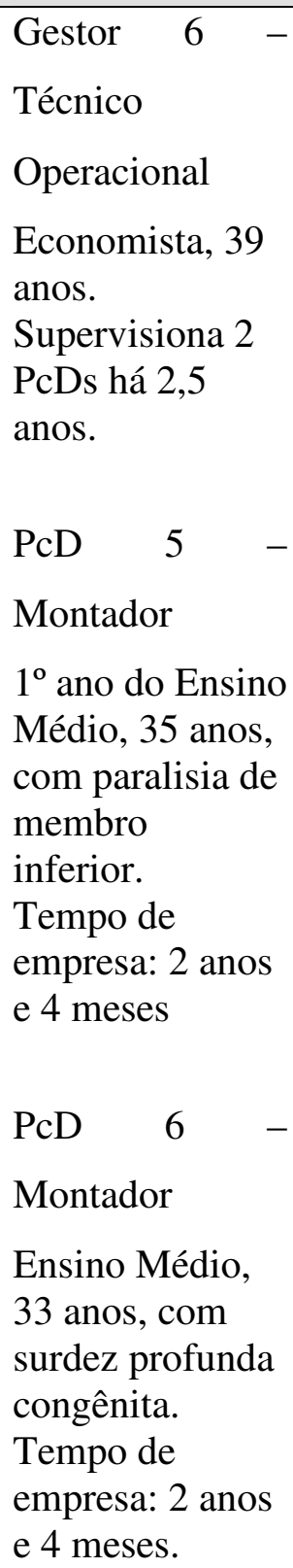 \\
\hline
\end{tabular}

Figura 2 - Perfil dos entrevistados

Fonte: elaborado pelas autoras.

\section{Apresentação e análise dos dados}

É importante esclarecer que foram selecionados para ser inclusos neste artigo os depoimentos considerados mais representativos.

\subsection{Significado de inclusão no discurso dos gestores e PcDs}

\subsubsection{O que se entende por inclusão}


Tomando por referência o modelo de Sandberg (2000), trata este item de entender as concepções dos atores do processo inclusivo que desencadeiam seu comportamento e ações. Na primeira concepção, que emerge dos discursos, inclusão é entendida como um ato de integração, de participação no sistema de trabalho, respeito aos limites, de maneira que a PcD se sinta bem em seu contexto de trabalho.

É a participação dele no contexto normal, sem ter processo especial. Inclusão são os
dois lados: fazer com que ele participe da maneira mais comum possível e também
não inventar que, pela deficiência, não vai conseguir participar (Gestor 1 -
multinacional de agronegócios)
Inclusão é dar espaço para que as pessoas se integrem. (Gestor 2- multinacional de
agronegócios
Inclusão? (pausa) A gente ouve a palavra inclusão, é de você incluir alguma coisa, de
você colocar no seu sistema uma coisa diferente, entendo isso como inclusão. No
caso, incluir pessoas que, de uma certa maneira, têm alguma deficiência, mas incluir
ela no dia-a-dia, como você pode incluir estas pessoas no seu sistema de trabalho.
(Gestor 3 - automotiva multinacional)

Um ponto a destacar é a referência à participação com respeito às capacidades e limites da PcD. Depreende-se que uma inclusão plena depende do posicionamento do gestor, de sua capacidade de entender como viabilizar tal participação, o que implica substituir concepções errôneas sobre a deficiência que podem levá-lo a limitar a atuação da PcD.

Um segundo aspecto que se destacou nas concepções dos entrevistados é o de que inclusão é uma questão de igualdade, que deve ser tratada de maneira natural. Trata-se de olhar o ser humano em sua diversidade intrínseca, própria de sua natureza. Neste contexto em que aspectos legais não são o ponto central de atenção, mas, sim, a aprendizagem que decorre da convivência com o naturalmente diferente - a PcD deve ter e saber de sua importância no sistema como um todo, seja ele social ou organizacional:

Para mim inclusão é fazer com que eles façam parte da nossa vida, da maneira mais
natural possível, é tratá-los de igual pra igual. [...] Fazer com que eles façam parte do
grupo como um todo, que eles saibam da importância deles no processo completo que
são todos os departamentos, todas as atividades. [...] Isso pra mim é inclusão, que tem
que ser feita da maneira mais natural possível e não de maneira obrigatória. Não
porque é 'Ah, é agora nós somos obrigados a contratar!' A gente aprende muito com
eles. (Gestora 4 - editora multinacional).
Para mim é muito forte essa palavra 'inclusão'. Eu acho que deveria ser um processo
natural, não ter inclusão de nada, não ter diversidade. É lidar com a coisa
naturalmente: é um empregado, como outro qualquer, é uma pessoa que merece mais
cuidados? [...] É realmente você aceitar o ser humano como ele é, sem fazer diferença.
(Gestora 5 - multinacional do setor de energia)

Em uma terceira concepção, inclusão significa proporcionar condições para que a PcD assuma a identidade social a que tem direito, promover a justiça, fazer com que as pessoas 
enxerguem seu valor e sua capacidade de contribuição; envolve, acima de tudo, trabalhar o olhar sobre a PcD. O gestor olhar para si e para o olhar de seus pares na organização:

Inclusão [...] é você buscar aquela pessoa que não existia perante a sociedade, que não tinha lugar para ela, que estava esquecida, estava de lado. É você mostrar para esse grupo que forma a sociedade que todos têm o seu valor e que todos têm a sua parcela de contribuição. É você abrir o leque, abrir espaço para aquela pessoa mostrar o seu valor. E fazer com que os outros abram a visão para entender e enxergar isso. (Gestor 6 - multinacional de tecnologia diesel)

O que estes relatos mostram é que a tarefa de incluir, seu significado, está fortemente arraigado em uma preocupação de ordem humanitária, humanística, que pode ser explicada pela incipiência das experiências inclusivas: viabilizar participação, naturalizar as relações com a PcD e desmistificar olhares preconceituosos e discriminatórios, aspectos fundamentais para que se criem condições para seu desenvolvimento, pois não há como pensar em aprendizagem da $\mathrm{PcD}$ se o ambiente não for propício. O que é preciso considerar é que tal ênfase é insuficiente para se promover inclusão plena, para garantir sua ascensão profissional.

Se o desenvolvimento das competências necessárias para que o gestor realize a inclusão depende do significado que o mesmo atribui ao ato de incluir (SANDBERG, 2000), a análise destes discursos sugere a necessidade dos gestores refletirem sobre o que é a inclusão em seu sentido pleno, transcendendo a questão do respeito, participação igualitária e justiça.

\subsubsection{O binômio inclusão/exclusão: os sentimentos das PcDs}

Dois indicadores podem ser considerados como o fiéis na balança do processo de inclusão: o quanto as PcDs se sentem incluídas ou excluídas e em que postos se encontram nas organizações. Sentimentos de pertencimento, de receber suporte, de serem aceitas, de participar, de terem o direito de cobrar e serem cobradas revelam, a partir dos sujeitos do processo, para que lado o binômio pende.

[...] Eu me dou bem com todo mundo. [...] Quando tem um evento, uma festa de fim de ano, eu consigo me dar bem em todas as rodinhas assim, em todos os departamentos. (PcD 1 - amiotrofia espinhal - multinacional de agronegócios)

[...] Eu acho que é um mundo perfeito no meu caso. Desde a aceitação pessoal quanto à questão de equipamentos, condições para trabalhar, a [nome da empresa] me oferece isso e eu não tenho dificuldade. (PcD 2 - amputação de membros superiores automotiva multinacional)

Eu não me sinto excluído em nenhum momento, a empresa me dá todo o suporte, por exemplo, as rampas... aquele corrimão e tudo. [...] Se eu errei, eles vão me cobrar, se eu acertei, eles vão me aplaudir. [...] Quando têm festas, eu vou; quando tem evento fora que eles me chamam, eu vou; treinamentos eu vou. (PcD 3 - paraplegia de membros inferiores - editora multinacional)

Desde o momento que eu entro aqui dentro, eu sinto que eu faço parte de uma família. E essa família me aceita como eu sou, entendeu? Se eu preciso de alguma coisa me 
ajudam. (PcD 4 - paralisia parcial de membros inferiores - multinacional do setor de energia)

Sou da empresa, tenho orgulho de trabalhar quando passo o crachá. Eu me sinto querido por todos. Todo mundo te cumprimenta, você dá bom dia o pessoal olha dentro do seu olho, abre aquele sorriso. (PcD 5 - paralisia de membro inferior multinacional de tecnologia diesel)

Eu me sinto [incluído]. É uma empresa muito boa para trabalhar, eu gosto de todo mundo, não tenho problema. Quando a gente vai ter alguma reunião, alguma coisa, eles sempre chamam aquela pessoa para estar auxiliando a interpretar, ou na refeição os caras vêm brincar comigo [...]. Então, eu me sinto feliz aqui (PcD $6-$ surdez profunda - multinacional de tecnologia diesel)

Embora as pessoas entrevistadas afirmem que se sintam incluídas, é importante observar que muitas vezes a exclusão pode estar incutida nas relações sociais (QUINTÃO, 2005). A PcD 1, com amiotrofia espinhal, ilustra esse ponto, quando fala sobre o local da confraternização de Natal preparada pela equipe que tinha escadas e que para a PcD e os colegas somente se deram conta que ela não poderia subir a escada sozinha quando chegaram ao restaurante. Apesar da experiência e da 'dica' da PcD para na próxima vez escolherem um local mais adequado, a confraternização do ano seguinte foi realizada no mesmo espaço. “ $E u$ pensei tudo bem... mas não está certo. [...] Então acabei não indo no amigo secreto, meio que de protesto. Eu aceito [ser carregado], mas não é o ideal, ainda mais sabendo que eu não tenho que passar por isso." (PcD 1 - amiotrofia espinhal).

A despeito do fato de que uma empresa pode ter uma grande preocupação em garantir a acessibilidade no trabalho, a realização de alguns eventos do qual a PcD não pode participar por falta de adaptações que considerem suas necessidades específicas revela que a palavra 'participação' deve ser revista e ampliada.

Teve esse evento de corrida de aventura que eu me senti mal, eu não vou mentir porque é verdade, eu me senti mal [...] Eu sei que era uma corrida de bicicleta e tudo, só que nem todo mundo consegue andar de bicicleta. Eu, por exemplo, consigo andar naqueles triciclos grandes [...] Eu acho que deveriam ter feito algo paralelo, no mesmo evento, só que uma coisa que a gente conseguisse fazer. Uma atividade que a gente conseguisse fazer e se sentisse bem junto ali com todo mundo, mas não é isso que acontece. Às vezes, muitos eventos não têm adaptação para a gente. (PcD 4 - paralisia parcial de membros inferiores - multinacional do setor de energia)

O que realmente é participação e em quais contextos ela é considerada? Como a empresa pode garantir essa interação, levando-se em conta os limites da PcD? A participação poderia ter início ao se dar voz a pessoa com deficiência. Seria uma ação simples reunir algumas PcDs no momento da organização de um evento, de maneira a permitir que elas mesmas se posicionassem sobre uma forma de participação que considerassem viável. As perguntas relativas à inclusão, à participação da $\mathrm{PcD}$ no contexto organizacional não estão todas respondidas. Cada caso deve ser trabalhado na medida em que se apresenta. 
A falta de acessibilidade atitudinal é outro fator que gera sentimentos de exclusão, já que são carregados de preconceitos e estereotipia, que, conforme observam Cox e Baele (1997), representam a maior barreira que uma PcD tem de enfrentar. Na fala a seguir se pode observar um comportamento típico de generalização da deficiência:

Tem algumas pessoas que às vezes discriminam, pensam que porque eu sou surdo sou
limitado. Acham que todos os surdos são iguais, eles generalizam e não é. Eu sou
inteligente, eu posso fazer as coisas também. Tem algumas pessoas que são super
legais, divertidas, mas têm outras que eu me sinto um pouco discriminado, sim, com
relação a eles, por algumas brincadeiras, alguns olhares. Mas eu fico quieto. (PcD 6 -
surdez profunda)

O que realmente é participação e em quais contextos ela é considerada? Como a empresa pode garantir essa interação, levando-se em conta os limites da $\mathrm{PcD}$ ? A participação poderia ter início ao se dar voz à pessoa com deficiência. Seria uma ação simples: reunir algumas PcDs no momento da organização de um evento, por exemplo, de maneira a permitir que elas mesmas se posicionassem sobre formas viáveis de participação.

Os relatos mostram que a criação de uma organização, uma sociedade inclusiva ainda está longe de ser uma realidade plena. Para se entender a dialética inclusão/exclusão é necessário colocar-se no lugar daquele que se sente excluído. "O sofrimento é experimentado como dor apenas por quem vive a situação de exclusão” (SAWAIA, 2004, p. 102).

\subsubsection{Relações interpessoais no trabalho e os desafios da inclusão}

Esta categoria analisa o comportamento inclusivo e a forma como relações interpessoais se estabelecem entre gestores, PcDs e equipe. Trata de entender os discursos, ações e sentimentos desses atores em suas relações cotidianas, já que, conforme observam Carvalho-Freitas e Marques (2006), o tratamento dado à PcD derivará da concepção que se tem da deficiência. Tal categoria divide-se em duas subcategorias: as relações entre o gestor e a $\mathrm{PcD}$ e relações entre a $\mathrm{PcD}$ e a equipe de trabalho.

O primeiro contato com a $\mathrm{PcD}$ pode causar, a princípio, um certo receio nas pessoas que participam de um processo de inclusão. A falta de informação e de convivência com uma PcD pode explicar sentimentos de apreensão sobre a melhor forma de agir.

No começo, eu acho que toda equipe ficou meio sem saber como fazer, como direcionar, como tratar esta pessoa, até porque a gente não conhece. Então você não sabe até onde pode brincar, até onde pode comentar, até onde você pode falar, até que ponto que a pessoa aceita o jeito dela por ela mesmo. (Gestor 3 - automotiva multinacional)

Eu fiquei com medo quando recebi essa missão, porque eu achei que eu não ia saber lidar com isso, porque o gestor, em muitos momentos, é emocional. Eu falei 'Meu 
Deus do céu, acho que eu não vou conseguir lidar, eu acho que eu vou ficar com pena, com dó!' E não, sabe? Eu encarei, peguei a missão pra mim, porém fiquei receosa [...] (Gestora 4 - editora multinacional).

Um comportamento típico que se observa nos discursos nessas situações é a tentativa dos pares profissionais de, muitas vezes, tentarem 'adivinhar' as necessidades da PcD:

No primeiro dia de trabalho dele a gente ficou imaginando 'E se ele precisar disso?' Principalmente para ele que tem uma limitação física bem grande. A gente ficava imaginando: será que eu vou ter que todo dia levantar e ligar o computador dele? Será que eu vou ter que atender ao telefone para ele e colocar no ouvido dele? Será que eu vou ter que levá-lo no banheiro? [...] Como a $\mathrm{PcD}$ ia trabalhar muito comigo, o gerente falou 'Você é muito brincalhão, cuidado com o que você fala, pode magoá-la.' (Gestor 1 - multinacional de agronegócios)

Além do receio, a visão estereotipada da deficiência interfere na crença da capacidade produtiva da pessoa. No caso do gestor 3 (automotiva multinacional), o primeiro contato o fez questionar sua capacidade de trabalho. A deficiência foi vista no lugar da pessoa: o fenômeno da generalização da incapacidade se fez presente (GOFFMAN, 1975), gerando uma expectativa de desempenho inferior (CARVALHO-FREITAS; MARQUES, 2006).

Eu estava de férias e quando eu cheguei com certeza minha impressão foi 'pegaram uma pessoa que não vai me adiantar porque eu vou ter que fazer o trabalho por ele, vou ficar mais sobrecarregado.' Esse foi o meu primeiro momento. [...] 'Ele não tem os membros superiores, ele vai trabalhar para mim diretamente no computador, como ele vai digitar os dados para mim? Como ele vai fazer um apontamento do pessoal da fábrica, sendo que ele não tem os membros superiores'? (Gestor 3 - automotiva multinacional)

Contudo, sentimentos de receio também foram observados nas falas das PcDs, revelando a insegurança da pessoa que se sente estigmatizada em relação à reação das pessoas que o receberão em um novo contexto (GOFFMAN, 1988). Todos os relatos corroboram as idéias de Fineman (2001) sobre as emoções colocarem a racionalidade das pessoas em xeque. A categoria 'deficiente' tem uma representação social ainda bastante influenciada pelo paradigma biológico, mesmo que a fala racional seja balizada pela questão da capacidade. A visão da $\mathrm{PcD}$ suscita sentimentos e pensamentos mobilizados pelo parâmetro da eficiência, tão fortemente arraigado no contexto organizacional.

Esses sentimentos iniciais, oriundos da visão fragmentada da $\mathrm{PcD}$, foram sendo, mesmo que parcialmente, revistos e substituídos na convivência diária, o que teve impacto no desempenho desses profissionais. Quanto mais severa é a deficiência, maior o impacto, como no caso da PcD com amiotrofia espinhal:

A princípio vem à mente: tem deficiência. Você não conhece o profissional que está aí e esse impacto foi grande. Mas na entrevista mesmo se chegou à conclusão que ele era o profissional ideal para assumir a vaga e que foi aberta para não-deficientes. (Gestor 1 - multinacional de agronegócios) 
Os padrões de avaliação do gestor 1 começaram a mudar quando percebeu a capacidade profissional da $\mathrm{PcD}$, "[...] Porque profissionalmente não teve nenhuma... nenhuma queda por ele ter uma deficiência”. Na verdade, ele respondeu muito bem ao parâmetro da eficiência vigente, surpreendendo a todos: "A maioria das atividades para as quais ele foi contratado fazia com alto índice de qualidade. Não era assim uma coisa simples e ele conseguia fazer muito bem feito."

O ajuste de visões a partir de um maior contato com a PcD 2 (amputação de membros superiores - automotiva multinacional) também ocorreu com o gestor 3 (automotiva multinacional), quando a viu sentar-se e digitar com o pés sem problema algum.

[...] Essa vivência com esta pessoa mudou um pouco esse impacto inicial. Não que eu achasse que as pessoas que tinham uma certa deficiência não tinham capacidade de desenvolver alguma atividade. Eu sempre fui muito aberto, mas eu não tinha vivenciado isso. (Gestor 2 - multinacional de agronegócios)

A representação social da deficiência somente pode ser ajustada quando o contato se estabelece: as pessoas passam a rever seus posicionamentos e a compartilhar as mesmas visões. O contato é uma das formas de se tratar o preconceito e os estereótipos, conforme preconizado por Allport (1958).

$\mathrm{Na}$ visão das PcDs, o relacionamento com o gestor deve balizado pelo tratamento igualitário, um relacionamento aberto, que cobra e orienta:

Ele trata da mesma maneira que as outras pessoas da equipe. Tenho que fazer os relatórios de atividades que eu faço, tenho que documentar tudo... Manda que eu esteja em cópia em todos os e-mails. (PcD 1 - amiotrofia espinhal - multinacional de agronegócios).

Esse relacionamento com a liderança é muito bom. [...] É um conceito que todo mundo espera de liderança, de relacionamento aberto. É aberto a sugestões novas, a mudanças. [...] A liderança cobra do funcionário, o funcionário dá o feedback. .(PcD 2 - amputação de membros superiores - automotiva multinacional)

Ela senta, conversa, me explica as coisas, pergunta se eu tenho alguma dúvida. (PcD 4 - paralisia parcial de membros inferiores - multinacional do setor de energia)

Não tem aquele 'passar a mão' porque é portador. Ao contrário, se você quer alguma coisa você deve ter que correr atrás, vai ter que crescer junto. Não é porque você é portador que vai ficar ali encostado em um canto, achando que ninguém vai te ver. Se você não está servindo para a empresa, tchau! (PcD 3 - paraplegia de membros inferiores - editora multinacional)

A gente brinca, ri, quando você erra, ele chama a atenção que ninguém é perfeito. (PcD 5 - paralisia de membro inferior - multinacional de tecnologia diesel)

Ele está sempre me olhando, sempre me vigiando, perguntando se eu estou bem, se está faltando alguma coisa. Meu chefe está sempre prestando atenção em mim. (PcD 6 - surdez profunda - multinacional de tecnologia diesel) 
São comportamentos que já demonstram uma acessibilidade atitudinal, que revelam uma preocupação da liderança com o desempenho profissional da PcD. Os discursos dos gestores são aderentes à visão das PcDs:

Conversei com ele: 'Olha, a gente vai trabalhar junto, meu sistema de gestão é esse, preciso que você desenvolva isso'. Depois, quando ele estava mais integrado, ele pôde desenvolver o trabalho normal. (Gestor 3 - automotiva multinacional).

Na minha área, todos estão misturados, efetivos, cooperados, estagiários, PNEs, e eles fazem as mesmas atividades; não tem uma atividade que é só do PNE. Não é aquela coisa que diferencia pela condição física da pessoa. (Gestora 4 - editora multinacional)

[...] É uma relação de transparência muito grande que você tem que ter com eles. Você tem que

ser muito objetivo, muito claro, não é pelo fato de ser PNE que você tem que ficar cheio de cuidados. (Gestora 5 - multinacional do setor de energia)

Contudo, é importante observar que tratamento igualitário envolve respeitar a diferença e trabalhar com as limitações que são inerentes à $\mathrm{PcD}$ : “Todos, na verdade, são preparados para respeitar os limites.” (Gestor 6 - multinacional de tecnologia diesel).

Um aspecto relevante deste processo é a postura adotada pelas PcDs. As falas, mais uma vez, reforçaram que o posicionamento da $\mathrm{PcD}$ em relação à sua deficiência diante de seus pares contribui para o estabelecimento de novos sentidos para as relações vividas no contexto de trabalho. Isso demonstra a necessidade da própria PcD em desmitificar discursos, romper estigmas e propor o estabelecimento de condutas adequadas que não sejam superprotetoras ou limitantes. Isso só é possível quando a PcD tem o que Mopfu e Harley (2006) chamam de identidade saudável da deficiência: "Tratar igual. Se você trata diferente, tem portadores que gostam, que eu conheço. Mas se eu sentir que eu estou em um lugar porque eu sou portador eu já ponho a minha mochilinha nas costas e vou embora. (PcD 3 paraplegia de membros inferiores - editora multinacional).

O modo como cada $\mathrm{PcD}$ se posiciona dentro do contexto intergrupal de trabalho influencia a forma como as demais pessoas a enxergarão e se relacionarão com ela. Assumir seu papel no processo produtivo e ter voz e participação no grupo torna-se fundamental.

\subsection{O processo de aprendizagem e o desenvolvimento de competências}

\subsubsection{Formas de aprendizagem}

Sem desconsiderar a importância de uma preparação formal, os relatos dos gestores enfatizaram, sobretudo, a aprendizagem por meio da experiência do dia-a-dia, seguida de coaching, experiências estas que permitem o exercício do diálogo e da reflexão como uma 
forma de promover o desenvolvimento tanto individual quanto grupal. Tais relatos estão de acordo com a importância que a literatura em aprendizagem e competências vem atribuindo à conversação (BAKER; JENSEN; KOLB, 2005) e ao diálogo reflexivo (SANDBERG; DALL'ALBA, 2006, p. 114), “[...] o diálogo genuíno envolve o processo de pergunta e resposta, com prioridade para as questões sobre as respostas".

As experiências compartilhadas compõem um 'repertório' que os gerentes podem usar como referência quando novas situações se apresentam no cotidiano do processo de inclusão.

[...] Esta convivência com as pessoas foi um aprendizado muito grande. Foi e está sendo um aprendizado a cada dia para todos. (Gestor 3 - automotiva multinacional)

A [nome da empresa] não preparou os gestores. Fui aprendendo no dia-a-dia, convivendo com as PNEs. (Gestora 4 - editora multinacional)

A reflexão após a ação aparece como um processo relevante, corroborando as colocações de Preskill e Torres (2001), uma vez que a reflexão permite rever crenças, suposições e questionar modelos mentais. $O$ ato de refletir possibilitou mudanças de perspectiva de significado (FRIEDMAN et al, 2001):

Quando eu vi ele sentando e começando a digitar as coisas com os pés, foi uma coisa muito nova para mim. $\mathrm{Na}$ realidade eu diria até que um excelente aprendizado e isso me fez aprender muita coisa, repensar conceitos [...]. (Gestor 3 - automotiva multinacional)

Às vezes, a gente acha que sabe tudo, que está melhor que a outra pessoa, ou então que o fato de você não ser um PNE estaria acima [delas]. Ao contrário, quando você participa e vive o processo do dia-a-dia junto com eles, você se nivela, você pode ter até umas qualidades a mais, um preparo a mais, uma faculdade a mais. Mas as situações, a vida te proporciona situações em que você acaba se nivelando [...] (Gestora 5 - multinacional do setor de energia)

A gente aprende muito com eles, a gente começa olhar e fala 'A gente não tem tanto problema assim!' (risos) A gente começa até tirar força, da atuação e do desempenho deles, para enfrentar os desafios que são colocados diariamente para nós. $\mathrm{O}$ fator primordial: hoje em dia quando você fala: 'Determinada meta é difícil!', está colocando para ele também, ele vai conseguir. A gente sabe que toda vez que se coloca meta pra eles, eles vão lá e conseguem. E aí você olha assim, e você vai reclamar antes de tentar? (Gestor 6 - multinacional de tecnologia diesel)

O que é possível, até aonde pode ir a $\mathrm{PcD}$, do que ela precisa são questões desconhecidas dos gestores. Uma situação vivenciada pelo gestor 1 (multinacional de agronegócios) ilustra bem esse ponto. Como a PcD sempre foi tratada sem diferenciações em relação aos seus pares, ele deixou de perceber seus limites reais:

Eu fiquei pensando. Eu trabalhei a noite inteira até meio-dia do dia seguinte. Como tinha Coca-cola ${ }^{\circledR}$ para a gente tomar e eu tomei várias vezes, eu perdi a conta de quantas vezes eu fui ao banheiro, de quantas vezes tive que levantar para dar uma esticada e ele não fez isso uma vez! Só que eu só pensei nisso umas duas semanas depois que aconteceu 'Caramba como que...!' A gente ficou trabalhando e tal... Incrível, a gente fica pensando tanto no profissional que você não pensa na deficiência 
dele, que você não pensa nessas coisas. Eu tive que me erguer, esticar o músculo, fazer o sangue fluir e como ele fez? (Gestor 1 - multinacional de agronegócios)

Contudo, é importante considerar que, embora o relato do gestor sugira a presença de um processo reflexivo, este só vai cumprir totalmente seu papel se promover mudanças de comportamentos em novas situações. A reflexão deve ser uma prática consciente para que a aprendizagem aconteça, tem de provocar mudanças. Uma atitude natural em uma situação como esta, livre de constrangimentos, seria a de conversar com a $\mathrm{PcD}$, para entender as diferenças e como ela lidou com aquilo. A ausência deste diálogo pode contribuir para perpetuar o desconhecimento das questões específicas relativas àquela deficiência e impedir a promoção de melhorias que garantam tanto seu conforto físico-mental como seu desenvolvimento profissional.

\subsubsection{O processo de aprendizagem}

Esta subcategoria analisa os processos de aprendizagem vivenciados pelos gestores, dentro do conceito de Cox e Baele (1997): consciência, compreensão e ação. A nova experiência associada à falta de vivência anterior despertou em muitos gestores a necessidade de buscar conhecimento e informações que julgaram necessárias para lidar com a deficiência:

\footnotetext{
Na primeira semana que a PcD veio trabalhar aqui eu perguntei para o pai dela se eu teria, em algum momento do dia, que levar água para ela ou acompanhá-la no banheiro. O pai falou 'Se precisar ela vai te falar'. [...] Às vezes, a gente vai à lanchonete para tomar o café da manhã e hoje eu sei que ele tem um canudo para tomar o Toddy ${ }^{\circledR}$, o achocolatado. No começo, a gente não sabia, então perguntamos 'Você quer que a gente ponha para você na boca?' e ela respondeu: 'Não, não! Eu tenho um canudo aqui' (Gestor 1 - multinacional de agronegócios).
}

Tentar agir corretamente foi o fator que mobilizou o gestor 1 (multinacional de agronegócios) a conhecer mais sobre a PcD que trabalha sob sua supervisão. Esta busca se deu de várias maneiras: ora perguntando diretamente para ela, ora questionando os pais; por vezes pela observação; outras pela necessidade de administrar uma situação crítica em que a PcD se via em visível dificuldade, mas não solicitava ajuda. Hoje sabem, por exemplo, de que, quando precisam entregar documentos para que ela leve para casa, existe uma bolsa que fica na lateral da cadeira-de-rodas, mas, no início, não foi assim.Isso sugere que os dois lados não souberam como agir, gerando uma postura reativa. A audiência deixa as coisas acontecerem, sem perguntar; a PcD não sinaliza suas necessidades.

Fica evidente que o processo de aprendizagem é complexo e sofre influência dos primeiros contatos. É necessário estabelecer um diálogo inicial para que se realize um 'contrato' de como as coisas podem e devem acontecer, como tratar, o que a $\mathrm{PcD}$ espera etc. Imaginar não é a forma mais adequada de ajustar estas percepções. A ação do gestor vai variar em função 
do grau de consciência sobre a necessidade de buscar informações para poder oferecer melhores condições de trabalho.

Recentemente, eu fiz um curso de acessibilidade e vi coisas novas no mercado que eu não conhecia. Até por conta deles mesmos, eu busquei, eu assisti uma palestra de uma pessoa que era portadora de necessidades especiais sobre acessibilidade. Ela fala de mercado, ela fala das competências, de novidades que tem de leitoras óticas, um monte de coisas que ajudam o deficiente no dia-a-dia dele. (Gestora 5 - multinacional do setor de energia).

Este relato exemplifica a importância do grau de consciência do gestor a que se referem Cox e Baele (1997), e que mobiliza a gestora a ter comportamentos que representem desempenho de alto nível no cumprimento de sua função diante das condições presentes.

A empresa na qual a gestora 5 atua realiza um treinamento para todos os funcionários para assimilação dos valores organizacionais e ela identificou que nem sempre a forma como as informações eram passadas eram compreendidas pelas PcDs com as quais trabalha. Ao perceber tais dificuldades, estruturou e ministrou um treinamento com dinâmicas, teatro e outras estratégias para facilitar o entendimento. Ao modificar as estratégias de ensino e aprendizagem, mostrou que assumiu a responsabilidade pelo trabalho com as PcDs e seu desenvolvimento, teve a iniciativa de criar novas respostas adequadas para enfrentar o evento com êxito e mobilizou recursos na ação (ZARIFIAN, 2001).

A reflexão diária possibilitou que a gestora 4 agisse para obter o melhor resultado com cada $\mathrm{PcD}$, saindo de uma condição de compaixão para um relacionamento profissional:

Eu não posso sentir pena, eu não posso sentir dó. Como é que eu vou avaliar uma pessoa, como é que eu vou contratar uma pessoa, como é que eu vou exigir de uma pessoa que ela me dê o retorno de um profissional? [...] Então, eu mudei pelo meu convívio direto com ele, ver como pensam, como encaram, como querem ser tratados. (Gestora 4 - editora multinacional)

O feedback fornece os elementos necessários para que a dinâmica do processo de aprendizagem aconteça. Esse feedback é o resultado do contato diário e da ampliação do conhecimento entre gestor e $\mathrm{PcD}$, que eleva o nível de consciência e compreensão do gestor e se traduz em novos comportamentos:

A ponto que a gente vai percebendo que ela $[\mathrm{PcD}]$ podia ir além do que eu estava
propondo inicialmente, no momento que eu incluía ele em alguma atividade nova, o
feedback dele era sempre assim, 'Não, eu dou um jeito, eu vou automatizar tal
planilha e consigo fazer essa tal coisa.' (Gestor 2 - automotiva multinacional) O aprendizado vai além das questões técnicas/profissionais, mas da própria forma de conviver com este outro que inclui a faceta do humor, da brincadeira. $\mathrm{O}$ aprofundamento da relação com a PcD permitiu ao gestor 3 repassar esse conhecimento ao grupo:

A partir do momento que eu percebi que poderia brincar, eu fui levando isso para o grupo, a ponto de eu mesmo começar a fazer algumas brincadeiras para que o grupo percebesse que ela estava no mesmo meio [...]. (Gestor 3 - automotiva multinacional).

REAd - Edição 69 - Vol. 17 - N 2 - maio/agosto 2011 - p. 360-395 
Os relatos dos entrevistados leva a depreender que o diálogo resultante das interações entre gestores e PcDs os induz a identificar a necessidade de recursos, compartilhar significados e entender a totalidade das situações. "É por meio do diálogo que os indivíduos fazem conexões entre si e comunicam interpretações pessoais e sociais que guiam o comportamento subseqüente” (PRESKILL; TORRES, 2001).

Como se pode verificar nos relatos dos gestores entrevistados, esse processo possibilitou o entendimento do modo de ser da $\mathrm{PcD}$ e de seu próprio, permitiu identificar como esta dinâmica entre ambos afeta o desempenho e levou os gestores a distinguir os caminhos a serem percorridos por eles e por cada uma das PcDs com as quais trabalha. Neste caso, gestores e PcDs foram autores e atores de seu processo de aprendizagem.

\subsubsection{Consequências da aprendizagem}

Sendo a aprendizagem bilateral, o indivíduo aprende que é capaz e o gestor aprende a respeitar as diferenças, a não discriminar. $\mathrm{O}$ aprendizado pessoal dá um novo significado às palavras limites e problemas.

No momento em que eu achava assim, já fiz um curso, está bom. Agora vejo esta pessoa fazendo faculdade com previsão de fazer uma Pós... Talvez até um mestrado, por que não? Eu achando que já estava bom o meu nível de conhecimento. Então este [risos] aprendizado vem mudando um pouco as nossas concepções. (Gestor 3 automotiva multinacional)

O valor agregado para o gestor também se apresenta sob a forma de satisfação de ter realizado um bom trabalho, de ter 'encarado o desafio' e ter obtido resultados:

[...] Para mim o grande resultado, o maior prazer, foi ver essas pessoas hoje bem colocadas, foram promovidas. Então isso pra mim é o maior resultado: você apostou e teve um retorno mais do que excelente. (Gestora 4 - editora multinacional)

O aprendizado permite ao gestor analisar o contexto de maneira holística: enxergar a si mesmo, enxergar a $\mathrm{PcD}$ e conseguir o entendimento prático da situação:

Eu mesma sou uma pessoa muito ágil, muito rápida, eu quero respostas rápidas, eu já nasci assim e acho que é difícil até mudar. Mas eu tive que aprender a ser mais paciente, mais tolerante, a me colocar no lugar do próximo (Gestora 5 - multinacional do setor de energia)

O valor agregado desse aprendizado também é relatado pelas PcDs. Como abordado anteriormente, uma maneira de se medir a inclusão é pelo sentimento daquele que é incluso e sua percepção de que realmente o gestor aprendeu nesse processo: tratamento igualitário, respeito, explorar as potencialidades e confiar na capacidade:

Se ele [gestor] tinha algum receio de me pedir para fazer hora extra, , ele aprendeu que eu posso fazer um esforço extra. Não precisa ter medo que eu vou me cansar, me machucar. Eu não preciso de nenhum mimo especial. Ele pode me tratar como 
funcionário normal, talvez seja essa a lição. Que ele pode me dar bronca, pode me cobrar, pode apertar os prazos, pode pedir para fazer hora extra. (PcD 1 - amiotrofia espinhal - multinacional de agronegócios)

[...] Ele às vezes fala: 'Você trabalha mais que outro aí,. Tem gente que não tem dificuldade e vocês trabalham mais do que eles' ([...] (PcD 5 - paralisia de membro inferior - multinacional de tecnologia diesel)

Um segundo ponto identificado pelas PcDs é que a experiência da inclusão afeta a todos: equipe, $\mathrm{PcD}$, gestor e ambiente.

Uma coisa que eu desenvolvi e os meus gestores que trabalharam comigo até hoje [fazem] foi se relacionar com as pessoas. Nesses cinco anos que eu fiquei no setor de usinagem, mudou para melhor! [...] Desde a liderança com os funcionários, funcionários com a liderança e funcionários com funcionários. (PcD 2 - amputação de membros superiores - automotiva multinacional)

Quando eu entrei só tinha PcD em um setor e hoje em dia está espalhado na empresa inteira. Então, ela [gestora] mostrou para todo mundo aqui dentro que ter portadores não é empecilho nenhum. (PcD 3 - paraplegia de membros inferiores - editora multinacional)

A gestora 4 (editora multinacional) cumpriu um papel maior do que aquele a que foi originalmente designado no programa de inclusão da empresa: o trabalho de inclusão de PcDs iniciado em sua área se expandiu pela empresa; o aprendizado se multiplicou.

O relato da PcD 6 leva ao próximo tópico de discussão. A PcD com surdez profunda remete ao posicionamento de Cox e Baele (1997), que trata de que o tipo de aprendizado necessário para o desenvolvimento das competências em diversidade está diretamente relacionado à composição do grupo ou sistema social, bem como à perspectiva de aplicabilidade desse aprendizado; neste caso, aprender sobre a cultura surda e, a partir desse aprendizado, ter uma ação adequada às necessidades e especificidades da PcD.

O meu chefe aprendeu algumas coisas, por exemplo, que o surdo precisa de atenção ao trabalho, o surdo não pode ficar olhando toda hora para todo lado, ele tem que prestar atenção ao trabalho, ou o surdo conversa ou o surdo trabalha. Então, ele aprendeu algumas coisas sobre cultura surda sim. (PcD 6 - surdez profunda multinacional de tecnologia diesel)

\subsection{Competências para a inclusão}

\subsubsection{Como o gestor compreende seu papel no processo de inclusão}

Uma conotação que emerge dos discursos dos gestores é que o papel deles exige o desempenho de várias atribuições: dar condições para a PcD desempenhar as atividades, delegar tarefas adequadas sem subestimar suas reais capacidades, entender seus limites, dar feedback autêntico e conhecer o que deixa a PcD confortável ou não:

Acredito que o papel é uma junção de diversos fatores: adequar e facilitar as atividades para que possam ser desempenhadas pela $\mathrm{PcD}$ sem subestimar sua capacidade física e intelectual. É importante descobrir seus limites e explorar as oportunidades. O gestor não pode se sentir constrangido em dar feedback, conversar 
para saber se ela se sente confortável com brincadeiras, expressões., que inevitavelmente poderão ocorrer. (Gestor 1 - multinacional de agronegócios)

O gestor 2 (multinacional de agronegócios) complementa a visão do 1, observando que o exercício desse papel pressupõe a quebra de paradigmas:

Eu nunca tinha trabalhado com uma PcD e essa experiência permitiu a gente quebrar essa barreira, esse bloqueio. Percebi que essa barreira foi quebrada, porque foi muito mais soberano o lado profissional, a capacitação e a competência (Gestor 2 multinacional de agronegócios).

O papel de integrador também é destacado e envolve incluir a PcD no sistema, no grupo, incluí-la em todas as instâncias, trabalhando as restrições que possam aparecer.

O papel do gesto é grande, porque, além de você incluir a pessoa no sistema, você tem que incluir no seu grupo de trabalho, ter uma sistemática para que o grupo todo aceite esta pessoa. O gestor tem que mostrar, muito calmo e naturalmente, que a inclusão tem que ser em todos os níveis: conhecimento, aprendizado, brincadeiras. (Gestor 3 - automotiva multinacional)

Porque existe preconceito, existe. [...] O papel do gestor é tentar promover o grupo, fazer com que haja um mínimo de homogeneidade. O grupo é único, eu quero que seja único, eu estou pedindo que a produtividade e as contribuições sejam relativamente iguais. Então a inclusão acaba acontecendo naturalmente. (Gestora 4 - editora multinacional)

A importância de se ter uma ação sistemática e frequente para que o grupo aceite a PcD de maneira natural é mencionada pelos gestores. Isso significa incluir também nas brincadeiras, a partir da maior convivência e entendimento da dinâmica da PcD. Contudo, o 'natural' não acontece por si só e cabe ao gestor assumir a responsabilidade de se posicionar sobre as atitudes esperadas no grupo e manter coerência entre seu discurso e suas ações. A inclusão é um processo bilateral, no qual todos aprendem juntos, no cotidiano.

Se considerarmos os contextos de acessibilidade propostos por Sassaki (2006), as falas dos gestores remetem-se a, pelo menos, quatro deles: garantir a comunicação, as atitudes adequadas à integração, os instrumentos de trabalho e os métodos e técnicas que permitam à $\mathrm{PcD}$ o desenvolvimento de suas potencialidades com respeito às suas limitações. O papel de professor também aparece como fundamental, uma vez que o gestor pode até garantir os elementos de acessibilidade necessários sem se dispor a ensinar ou a mostrar a importância do saber, orientar, direcionar, conversar e motivar a PcD.

No começo, até os cursos que eles tinham que fazer - um curso de recepção, curso de etiqueta - eu acabei participando junto com eles, porque a gente tem alguns casos que têm dificuldade até de entendimento. Eu até participava junto como instrutora deles, explicando: 'Olha, ele falou isso, você entendeu?' 'Se não entendeu, pergunta!'. Ou, então, depois que a pessoa saía: 'Vamos discutir o que foi falado aqui?', e acabava tendo um debate aberto para a pessoa fixar melhor. (Gestora 5 - multinacional do setor de energia)

O papel do gestor acaba sendo um conjunto de tudo: profissional, pai, amigo, irmão. Saber como dirigir as palavras com as pessoas, porque, ao mesmo tempo você precisa 
passar onde ela está acertando, [...]você precisa passar onde ela está errando, de forma que ela compreenda e não leve para o lado pessoal. (Gestor 6 - multinacional de tecnologia diesel)

Adequar, facilitar, explorar oportunidades, dar feedback, conversar, quebrar barreiras, incluir, treinar, solicitar, promover são verbos usados pelos gestores para indicar suas ações. $\mathrm{O}$ quanto estes verbos se combinam ou atuam isoladamente é o que interessa saber. A competência se dá pela combinação dos verbetes que, interligados, podem representar ações conjuntas muito favoráveis em direção à promoção intelectual e profissional da PcD.

\subsubsection{Competências necessárias para se fazer a inclusão na visão das PcDs e dos gestores}

O quadro, a seguir, sumariza as competências identificadas pelas PcDs e pelos gestores como necessárias para que estes últimos realizem a inclusão e foi organizado de acordo com a estrutura de comparação intergrupos proposta por Gil Flores (1994) e se baseia na classificação de competências do modelo de Cheetam e Chivers (1996, 2005).

\begin{tabular}{|c|c|c|c|c|}
\hline & $\begin{array}{l}\text { Competência } \\
\text { Cognitiva }\end{array}$ & $\begin{array}{l}\text { Competência } \\
\text { Funcional }\end{array}$ & $\begin{array}{l}\text { Competência Pessoal } \\
\text { ou } \\
\text { Comportamental }\end{array}$ & $\begin{array}{l}\text { Competência } \\
\text { Valores/Éticas }\end{array}$ \\
\hline \multirow{2}{*}{ 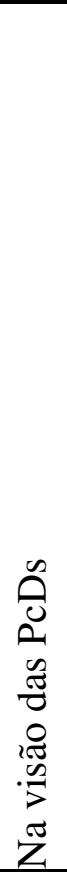 } & & $\begin{array}{l}{[\ldots . .] \text { Providenciar }} \\
\text { estrutura e } \\
\text { equipamentos } \\
\text { necessários [...] Tem } \\
\text { que delegar funções } \\
{[\ldots][\ldots] \text { Dar todo o }} \\
\text { suporte para a } \\
\text { pessoa trabalhar }[. . .] \\
\text { Qualificar a pessoa. } \\
\text { [...] Dar o suporte } \\
{[\ldots] \text { Tem que exigir, }} \\
\text { mas dar as } \\
\text { condições }[\ldots]\end{array}$ & \begin{tabular}{|l} 
[...] Deixar a pessoa à \\
vontade para não se \\
sentir constrangido em \\
pedir as coisas [...] \\
[...] O líder precisa \\
olhar essa questão \\
humana, tem que ser \\
uma pessoa aberta \\
[...] Pôr na equipe [...] \\
[...] Quando a pessoa \\
erra, o chefe está \\
ajudando, ele não \\
chama a atenção, e \\
não dá bronca, ele \\
ajuda e ele explica \\
onde você errou. [...]
\end{tabular} & $\begin{array}{l}{[\ldots] \text { Abraçar a causa }} \\
{[\ldots . .] \text { Tratar como uma }} \\
\text { pessoa normal. [...] } \\
\text { [...] Ver e tratar igual } \\
\text { em primeiro lugar } \\
{[\ldots]} \\
{[\ldots] \text { Todo líder }} \\
\text { precisa dar uma } \\
\text { atenção especial a } \\
\text { eles [pessoas surdas], } \\
\text { pelo menos no } \\
\text { começo [...] ele tem } \\
\text { paciência comigo }[. . .] \\
\text { O jeito que ele é } \\
\text { comigo ele é com os } \\
\text { ouvintes também. }\end{array}$ \\
\hline & \multicolumn{4}{|c|}{$\begin{array}{l}\text { Meta-competências [...] Perguntar: 'Entendeu?' Como que é possível, quais os tipos } \\
\text { de coisas que você consegue fazer com aptidão [...] }\end{array}$} \\
\hline
\end{tabular}




\begin{tabular}{|c|c|c|c|c|}
\hline 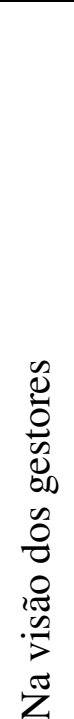 & $\begin{array}{l}{[. . .] \text { Conhecer a }} \\
\text { deficiência de } \\
\text { cada um }[. . .]\end{array}$ & $\begin{array}{l}\ldots . .] \text { Conhecê-lo } \\
\text { como profissional } \\
{[\ldots . .]} \\
{[\ldots] \text { Tem que }} \\
\text { conhecer a pessoa e } \\
\text { saber identificar o } \\
\text { potencial dessa } \\
\text { pessoa }[. . .] \\
{[\ldots .] \text { Dar condições }} \\
\text { de trabalho }[. . .] \\
\text { Saber adequar a sua } \\
\text { necessidade de } \\
\text { trabalho com as } \\
\text { limitações que as } \\
\text { PcDs apresentam. }\end{array}$ & $\begin{array}{l}{[\ldots] \text { Saber lidar com as }} \\
\text { pessoas }[. . .] \\
{[\ldots] \text { O dom de }} \\
\text { observar }[. . .] \\
{[\ldots] \text { Se coloque na }} \\
\text { posição do outro }[. . .]\end{array}$ & $\begin{array}{l}\text { [...] Tratar com } \\
\text { igualdade no sentido } \\
\text { da cobrança da } \\
\text { atividade [...] } \\
\text { Quebrar o paradigma } \\
\text { [...]. } \\
{[\ldots .] \text { Eu falo em }} \\
\text { humildade } \\
\text { [...] Tratamento } \\
\text { absolutamente } \\
\text { normal. } \\
\text { [...] E muita paciência } \\
\text { também }[. . .]\end{array}$ \\
\hline
\end{tabular}

Figura 3 - Competências necessárias para inclusão

Fonte: elaborado pelas autoras.

Cabe observar que o enquadramento dos dados nos componentes das competências do referido modelo é um exercício teórico, uma vez que, como os próprios autores pressupõem, há grande interação entre as dimensões de competências, o que muitas vezes torna difícil separar ou inserir os dados em uma única categoria. Outro ponto a ser salientado é que, por ser uma pesquisa de origem qualitativa, o enquadramento do discurso dos entrevistados nas competências cognitivas, funcionais, comportamentais e éticas/valores levou em consideração o contexto da entrevista na qual o mesmo está inserido. As meta-competências somente são indicadas nos quadros de análise quando efetivamente apontadas pelos entrevistados.

Para as PcDs, o tratamento igualitário e a cobrança de resultados levando em conta suas capacidades e limitações são as competências mais ressaltadas, seguidas de comunicação aberta e acompanhamento do desenvolvimento. As competências funcionais indicadas são aquelas consideradas como parte da função gerencial, relacionando-se às condições que o gestor provê para que a PcD possa ser bem sucedida em suas atividades, e que envolvem tanto os recursos necessários como também sua capacitação. Apenas duas das PcDs indicaram a comunicação como uma competência importante. O conjunto das demais competências que as PcDs reputam como necessárias para o gestor fazer a inclusão sugere que a comunicação é um aspecto subjacente ao uso de outras competências, tais como explicar, relacionar-se, qualificar. Por outro lado, é importante chamar a atenção à necessidade de o gestor conhecer a deficiência e entender as necessidades da PcD. Para isso, ele tem de reconhecer que não sabe as reais necessidades da $\mathrm{PcD}$ e que precisa conversar com ela para alcançar esse entendimento, pois supor suas necessidades pode levá-lo a erros. 
Outra competência que apareceu com maior incidência é a de providenciar estrutura e equipamentos necessários. Essa ação é sustentada pela consciência do gestor sobre seu papel no processo inclusivo, que o leva a compreender a $\mathrm{PcD}$ a partir do conhecimento de suas necessidades e agir no sentido de atendê-las. Essas três fases - consciência, compreensão e ação - corroboram as ideias de Cox e Baele (1997) sobre competências em diversidade.

Muitos dos aspectos identificados como competências pelas PcDs estão relacionados às competências éticas (CHEETHAM; CHIVERS, 1996; 2005) e à aplicação efetiva e apropriada de valores em contextos profissionais: ausência de preconceitos, comprometimento, abertura, sensibilidade, justiça na forma de tratar a PcD e, sobretudo, paciência, que, na visão de Cheetham e Chivers (2005), é uma competência crítica para a performance efetiva. Esta é uma competência importante para que o gestor exerça seu papel de professor, uma vez que ele é responsável por qualificar, explicar, orientar, corrigir, enfim, auxiliar a PcD a se desenvolver como profissional.

Para as PcDs, as competências que se sobressaem são as comportamentais e de ética/valores. O comportamento inclusivo do gestor e os valores e a ética que os sustentam são para elas os aspectos mais significativos. Para os gestores, o conhecimento dos limites e capacidades da PcD é a competência fundamental, seguida da capacidade de explorar suas potencialidades. Tal posicionamento é aderente ao pensamento de Cox e Baele (1997) sobre a redução do preconceito: ter a abertura para buscar e verificar informações sobre membros de outros grupos de identidade, distinguindo as reais diferenças intergrupais dos mitos, identificar estereótipos e desafiar a si mesmo e aos outros a superar esses pressupostos.

Um dos gestores considera habilidade empática e conhecimento da deficiência como fatoreschave, complementados pelo saber lidar com sentimentos de baixa auto-estima, revolta, sensação de inferioridade, ou 'recalques', como afirmou uma das gestoras. É ter o interesse genuíno pelo assunto (COX; BAELE, 1997; MATVEEV; MILTER, 2004) e o entendimento prático da situação (ZARIFIAN, 2001). Querer, vontade e afinco são as palavras-chave de dois outros gestores, pois representam a atitude que sustenta um comportamento inclusivo e que está diretamente relacionada ao nível de consciência que o gestor tem sobre seu papel neste processo. A concepção dada pelo gestor para aquele trabalho (SANDBERG, 2000) e o sentido particular dado ao indivíduo para aquela atribuição em função de suas convicções o levam a assumir essa responsabilidade e a mobilizar seus saberes (ZARIFIAN, 2001; LE BOTERF, 2003).

Outros gestores acrescentam o ingrediente paciência, imparcialidade e saber lidar com as diferentes dinâmicas interpessoais a esse perfil. A convergência dos pontos de relevância 
identificados nos discursos dos gestores sugere um impacto profundo no exercício de seu papel, uma vez que representa a humanização das relações no trabalho. É interessante observar que a maioria das competências indicadas pelos gestores são relacionadas a valores/ética, sendo estes os pontos que julgaram como fundamentais para definir as decisões e ações apropriadas com as PcDs. Isso sugere uma mudança profunda em suas crenças, em sua forma de ser, pois o gestor passa a dar um novo significado ao ato de incluir.

Por fim, entender e respeitar a dinâmica das pessoas e saber lidar com as diferenças são as expressões mais recorrentes usadas pelos gestores, seguidas de paciência e respeito pelo tempo e o ritmo da PcD. O quadro abaixo sumariza as competências que os gestores reputam terem desenvolvido com a experiência da inclusão:

\begin{tabular}{|c|c|c|c|c|}
\hline & $\begin{array}{l}\text { Competência } \\
\text { Cognitiva }\end{array}$ & $\begin{array}{l}\text { Competência } \\
\text { Funcional }\end{array}$ & $\begin{array}{l}\text { Competência } \\
\text { Pessoal ou } \\
\text { Comportamental }\end{array}$ & Competência Valores/Éticas \\
\hline 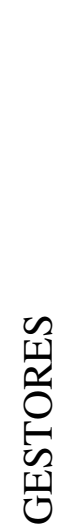 & $\begin{array}{l}{[\ldots] \text { Saber }} \\
\text { conversar } \\
\text { através de } \\
\text { gestos [Libras] }\end{array}$ & $\begin{array}{l}\text { [...] Explorar a } \\
\text { capacidade. }\end{array}$ & $\begin{array}{l}{[\ldots] \text { Saber lidar }} \\
\text { com as pessoas } \\
\text { que são diferentes } \\
{[\ldots]}\end{array}$ & $\begin{array}{l}\text { [...] Tratar com igualdade no } \\
\text { sentido da cobrança da atividade. } \\
\text { [...] Respeitando os limites [...] } \\
\text { [...] Quebrar esses paradigmas. } \\
\text { [...] Enxergar que todos têm a } \\
\text { mesma capacidade [...] ser } \\
\text { muito imparcial } \\
\text { [...] A paciência de conversar, } \\
\text { de falar, de respeitar, de entender } \\
\text { [...] A paciência [...] respeitar os } \\
\text { limites }\end{array}$ \\
\hline
\end{tabular}




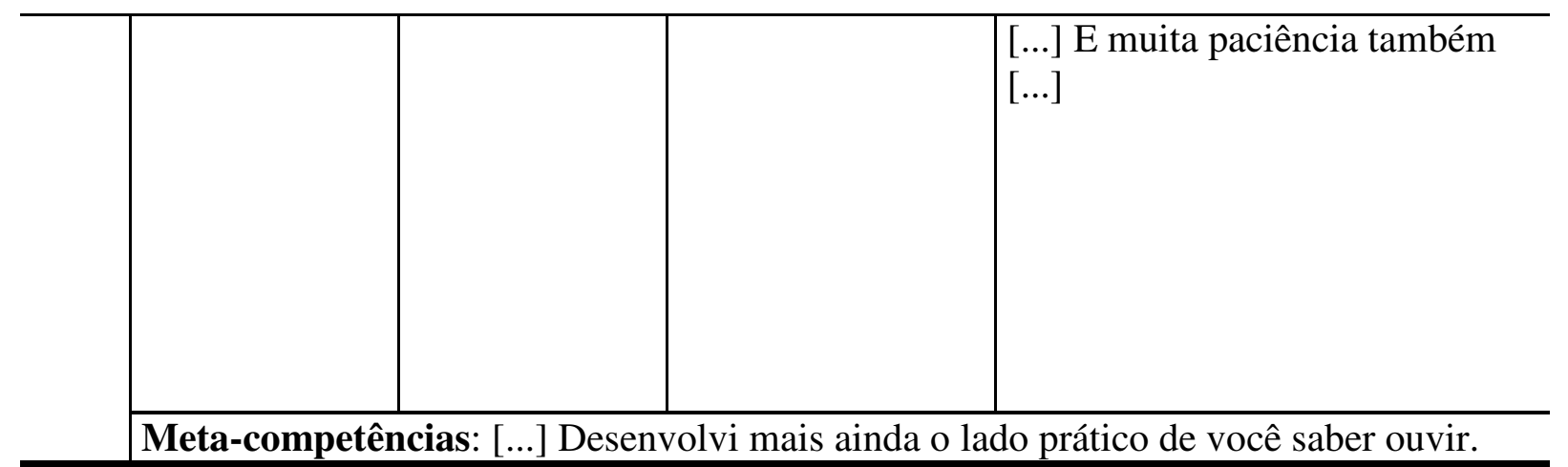

Figura 4 - Competências desenvolvidas pelos gestores

Fonte: elaborado pelas autoras

\section{Considerações finais}

A partir das análises desenhadas até aqui, o que se pode dizer sobre o papel dos gestores como agentes do processo inclusivo e os processo de aprendizagem e desenvolvimento de competências para a inclusão? Que implicações podem-se apontar das experiências em estudo para a $\mathrm{PcD}$, os gestores e a gestão?

Em relação ao significado da inclusão, não se observou avanços nas experiências em estudo em relação ao que a literatura vem apontando nos últimos anos sobre a posição da PcD nas organizações: os gestores não fazem referência a noções de empoderamento ou à progressão na carreira da $\mathrm{PcD}$, o que evidencia que o que mais os mobiliza, na verdade, é a ação social implícita no ato de incluir. Neste sentido, suas ações de inclusão e, portanto, suas competências, refletirão essa percepção (SANDBERG, 2000). Para as PcDs, incluir significa ter tratamento igualitário, ter oportunidades e recursos para trabalhar, o que implica, para elas, que o gestor esteja pré-disposto a quebrar preconceitos e tabus e a dialogar.

Também não se observou avanços em relação à posição hierárquica das PcDs entrevistadas, que, em sua maioria, ocupam cargos mais simples na estrutura organizacional. Criar condições para o desenvolvimento profissional será tarefa dos gestores com apoio da organização; caso contrário, o movimento será o de criar exclusão dentro do processo de inclusão (QUINTÃO, 2005; SASSAKI, 2006). Como se mostrou nas análises, poucas práticas apontaram para um comportamento voltado ao desenvolvimento e crescimento profissional da $\mathrm{PcD}$, em que o gestor discute as possibilidades de trabalho com ela e garante a autonomia para que desenvolva sua atividade da melhor maneira possível, sem necessidade de recorrer à supervisão com tanta frequência.

No que se refere ao papel dos gestores, as entrevistas evidenciam que estes desempenharam a função de integrador, de facilitador e, raramente, de promotor do 
desenvolvimento intelectual e profissional da PcD. A experiência da inclusão aumenta a complexidade da tarefa do gestor, porque exige outros parâmetros avaliativos, demanda um olhar diferenciado (BASTOS, 2001), que acaba resultando, como se pôde observar na pesquisa, na necessidade de maior humanização da relação, fruto de um aprendizado compartilhado (ARGYRIS, 1999). Já na perspectiva das PcDs entrevistadas, o papel do gestor é atentar para situações críticas que evidenciem comportamentos de exclusão e criar condições para que a PcD tenha voz na equipe de trabalho, em todas as situações, sejam profissionais e/ou sociais.

Quanto às relações interpessoais no trabalho, muitas das dificuldades em se realizar inclusão no contexto organizacional referem-se à visão fragmentada sobre a $\mathrm{PcD}$, que destaca possíveis limitações em detrimento de suas reais capacidades, percepção esta mobilizada pelo estereótipo (ALLPORT 1958). Isso porque o contato inicial com a PcD desestabiliza, gera resistências, mesmo quando as pessoas se propõem a trabalhar com ela: 'Não sei como fazer...', 'Não sei como lidar...', 'Primeiro precisamos...'. Na pesquisa, o receio foi o sentimento verbalizado por todos os gestores ao iniciarem o processo de inclusão.

Se o desconhecimento é o primeiro passo para a manutenção e fortalecimento de estereótipos, a convivência diária foi fundamental para que as percepções se ajustassem e as interações entre a $\mathrm{PcD}$ e as demais pessoas da equipe fossem produtivas. Apesar da maioria dos gestores ter PcDs em seus quadros de trabalho pela questão legal, observa-se que o contato diário os levou a mudar a impressão inicial e, consequentemente, a própria percepção sobre a deficiência. Como muitos se posicionaram, suas expectativas foram superadas.

De acordo com as PcDs entrevistadas, os gestores têm cumprido seu papel como agentes de inclusão. Contudo, como ficou demonstrado nos relatos, a exclusão também se fez presente em situações fora do contexto de trabalho, como eventos e festas de confraternização, ratificando o argumento de Quintão (2005): a exclusão pode estar incutida nas relações, uma vez que as pessoas não-deficientes muitas vezes tomam decisões sobre eventos sem antes consultar a PcD.

O relato dos gestores revelou que a ação consistente e coerente com cada situação de trabalho com a PcD depende de três fatores, conforme preconizam Cox e Baele (1997): o primeiro é a consciência da necessidade de se buscar maior entendimento da PcD; o segundo é a necessidade do gestor compreender sua própria dinâmica, suas facilidades e dificuldades em lidar com as diversas situações que vivencia; e o terceiro, a reflexão crítica sobre sua forma de gerenciar a inclusão da PcD. Isso vai possibilitar ao gestor fazer os ajustes necessários para ter um relacionamento pautado no profissionalismo e não mediado pela 
compaixão, pela superproteção ou pela dificuldade de assumir seu papel e comprometer-se efetivamente com o processo de inclusão.

Fica evidente que é um aprendizado compartilhado, uma experiência nova tanto para o gestor quanto para a PcD e que pode gerar uma postura reativa de ambos os lados: o gestor espera que a PcD se manifeste em relação às suas necessidades e a PcD aguarda a ação do gestor, sem sinalizar suas dificuldades. Isso sugere a existência de uma barreira inicial, um constrangimento que leva as pessoas a perder a espontaneidade que seria a esperada em um processo reputado pelos gestores entrevistados como algo que deve acontecer naturalmente.

Sugere, também, uma preocupação em não mostrar algum tipo de preconceito, como revelam as falas de gestores que dizem tratar a $\mathrm{PcD}$ como qualquer pessoa, ou ainda "como se fosse uma pessoa normal" (Gestora 4 - editora multinacional). Essa preocupação tende a tornar a expressão 'tratamento igualitário' superlativa e, portanto, pode fazer com que a diferença seja deixada de lado em uma situação na qual deveria ser considerada.

Sendo a aprendizagem bilateral, a PcD aprende que é capaz e o gestor aprende a respeitar as diferenças, a não discriminar. O gestor dá um novo significado às palavras 'limites', ‘participação', 'dificuldades', isto é, dá um novo sentido ao ato de incluir.

Finalmente, no que diz respeito ao desenvolvimento de competências, seguindo o modelo de Cheetham e Chivers (1996, 2005), pôde-se constatar que, embora os gestores tenham considerado como competências mais significativas para a inclusão as funcionais, as comportamentais e as éticas/valores, seus relatos ressaltaram que o que desenvolveram, de fato, foram as competências éticas/valores como respeito, humildade e paciência.

O quadro a seguir sintetiza os pontos identificados como fundamentais para o gestor realizar a inclusão de PcDs. O papel do gestor perpassa todas as categorias, uma vez que se entende que todos os pontos lhe são inerentes e ele pode contribuir para o aprimoramento das práticas e políticas de inclusão por todos os atores responsáveis pela gestão. Espera-se, assim, que sirva de parâmetro para que as organizações reflitam e encontrem seus próprios caminhos em direção à construção de uma inclusão competente.

\begin{tabular}{|c|c|c|}
\hline & PONTOS-CHAVE & \\
\hline 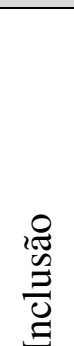 & $\begin{array}{l}\text { - Respeitar as capacidades e } \\
\text { limites da PcD, dar tratamento } \\
\text { igualitário. } \\
\text { - } \\
\text { Desenvolver processo } \\
\text { estruturado para receber a } \\
\text { PcD. } \\
\text { - Integrá-la no grupo e nas }\end{array}$ & $\begin{array}{l}\text { Prover os recursos } \\
\text { necessários: equipamentos, } \\
\text { layout, informações, fluxo de } \\
\text { trabalho, a partir do } \\
\text { entendimento das suas } \\
\text { necessidades específicas. } \\
\text { Permitir que a PcD defina suas }\end{array}$ \\
\hline
\end{tabular}

REAd - Edição 69 - Vol. 17 - N 2 - maio/agosto 2011 - p. 360-395 
Claudia Serrano \& Janette Brunstein

\begin{tabular}{|c|c|c|}
\hline & $\begin{array}{l}\text { atividades, de maneira que a } \\
\text { PcD crie identidade com a } \\
\text { empresa e assuma a } \\
\text { identidade social a que tem } \\
\text { direito. } \\
\text { - Permitir a emancipação da } \\
\text { PcD por meio do } \\
\text { reconhecimento de seu } \\
\text { potencial. Priorizar as } \\
\text { capacidades e, não, a } \\
\text { deficiência. }\end{array}$ & $\begin{array}{l}\text { necessidades em seus próprios } \\
\text { termos. } \\
\text { - Identificar com a PcD como } \\
\text { ela pode participar de } \\
\text { atividades extras promovidas } \\
\text { pela empresa: } \\
\text { confraternizações, eventos, } \\
\text { gincanas etc. } \\
\text { - Orientar no momento da } \\
\text { admissão. }\end{array}$ \\
\hline 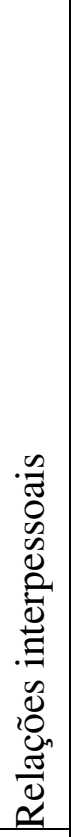 & $\begin{array}{l}\text { PcD x Gestor x Equipe } \\
\text { • } \\
\text { Identificar estereótipos e } \\
\text { preconceitos presentes na } \\
\text { equipe de trabalho e nas } \\
\text { interfaces com outras áreas. } \\
\text { - } \\
\text { Observar a maneira como a } \\
\text { PcD se posiciona frente à sua } \\
\text { deficiência e qual o impacto } \\
\text { do seu posicionamento nas } \\
\text { pessoas com as quais se } \\
\text { relaciona. } \\
\text { O gestor ser um modelo para } \\
\text { a equipe em relação às } \\
\text { condutas esperadas. }\end{array}$ & $\begin{array}{l}\text { Dialogar com a equipe e com } \\
\text { a PcD para estabelecer as } \\
\text { condutas adequadas no } \\
\text { relacionamento diário. } \\
\text { - Qualificar, orientar, delegar, } \\
\text { acompanhar e gerenciar o } \\
\text { desenvolvimento. } \\
\text { - Dar feedback transparente, } \\
\text { valorizar o desempenho. } \\
\text { Exercer o papel de } \\
\text { disciplinador quando } \\
\text { necessário. } \\
\text { Entender a deficiência: } \\
\text { dialogar com a PcD para } \\
\text { estabelecer o contrato de } \\
\text { trabalho e as formas de } \\
\text { relacionamento adequados. } \\
\end{array}$ \\
\hline \multirow[b]{2}{*}{ 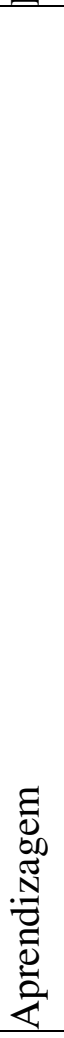 } & $\begin{array}{l}\text { Formas de aprendizagem } \\
\text { - Treinamento formal para } \\
\text { adquirir base cognitiva inicial. } \\
\text { - Aprender no dia-a-dia. } \\
\text { - Trocar experiências com } \\
\text { outras pessoas. }\end{array}$ & $\begin{array}{l}\text { - Coaching com a área } \\
\text { responsável pelo Programa de } \\
\text { Inclusão da empresa. } \\
\text { - Usar a PcD como fonte de } \\
\text { aprendizagem. } \\
\text { - Refletir, criticamente, sobre as } \\
\text { experiências. }\end{array}$ \\
\hline & $\begin{array}{l}\text { Processo de aprendizagem } \\
\bullet \quad \text { Consciência: considerar } \\
\text { legítima a necessidade de } \\
\text { aprender sobre a deficiência e } \\
\text { suas singularidades. }\end{array}$ & $\begin{array}{l}\text { Compreensão: adquirir um } \\
\text { entendimento profundo de } \\
\text { como e por que o } \\
\text { conhecimento da PcD é } \\
\text { relevante para o bom } \\
\text { desempenho da organização, } \\
\text { grupos e indivíduos e quais } \\
\text { são as mudanças necessárias } \\
\text { para serem efetivadas. Buscar } \\
\text { conhecimento. } \\
\text { Ação: mobilizar o } \\
\text { conhecimento, agir no sentido } \\
\text { de realizar as mudanças de } \\
\text { comportamento necessárias. }\end{array}$ \\
\hline
\end{tabular}


Claudia Serrano \& Janette Brunstein

\begin{tabular}{|c|c|c|c|}
\hline & $\begin{array}{l}\text { Cognitivas: } \\
\qquad \quad \text { Conhecer a deficiência }\end{array}$ & $\mathrm{cD}$ que atua na equipe & 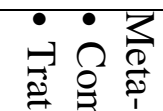 \\
\hline & $\begin{array}{l}\text { Funcionais: necessárias ao } \\
\text { exercício da função } \\
\text { - Desenvolver pessoas: } \\
\text { coaching e feedback } \\
\text { (Postura de professor). } \\
\text { - Prover estrutura. } \\
\text { - Delegar. }\end{array}$ & $\begin{array}{l}\text { - } \text { Cobrar resultados. } \\
\text { - Orientar. } \\
\text { - Conhecer a PcD como } \\
\text { profissional, identificar } \\
\text { potencial. } \\
\text { - Adequar as necessidades } \\
\text { de trabalho às limitações } \\
\text { presentes. }\end{array}$ & 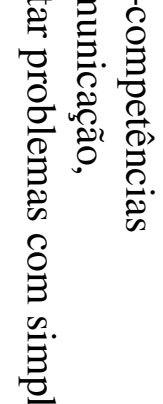 \\
\hline & $\begin{array}{l}\text { Pessoal/Comportamental } \\
\text { - Trabalho em equipe. } \\
\text { - Perceber e trabalhar a } \\
\text { diversidade, ser } \\
\text { observador. }\end{array}$ & $\begin{array}{l}\text { - Relacionamento aberto e } \\
\text { empático. } \\
\text { - Quebrar paradigmas, } \\
\text { mente aberta. } \\
\text { - Lidar com diferentes } \\
\text { dinâmicas interpessoais. }\end{array}$ & 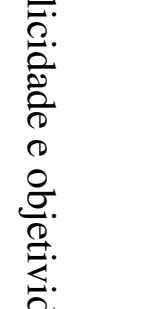 \\
\hline 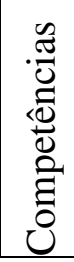 & $\begin{array}{ll}\text { Valores/Éticas } \\
\bullet \\
\text { • } \\
\text { - Rumildade. } \\
\text { Tratamento justo e } \\
\quad \text { igualitário. } \\
\end{array}$ & $\begin{array}{ll}\text { - } & \text { Comprometimento. } \\
\text { - } & \text { Paciência. } \\
\text { - Sensibilidade. }\end{array}$ & 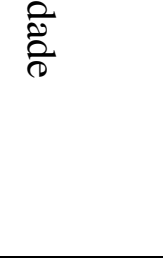 \\
\hline
\end{tabular}

Figura 5 - Pontos fundamentais para a inclusão

Fonte: elaborado pelas autoras

\section{REFERÊNCIAS}

ALLPORT, G.W. The nature of prejudice. Anchor Books Edition, 1958.

AMARAL, L. A. Conhecendo a deficiência. São Paulo: Robe Editorial, 1995.

APPELBAUM, S. H.; SHAPIRO, B.; ELBAZ, D. The management of multicultural group conflict. Team Performance Management. v. 1, n. 5, 1998.

ARGYRIS, C. D. On Organizational Learning. 2a ed. UK: Blackwell Business, 1999.

BAKER, A. C.; JENSEN, P. J.; KOLB, D. A. Conversation as experiential learning. Management learning, v. 36, n. 4, December, 2005.

BASTOS, A. V. Cognição nas Organizações de Trabalho. In: ZANELLI, J. C.; BORGESANDRADE, J.E.; BASTOS, A. V. Psicologia, organizações e trabalho no Brasil. São Paulo: Artmed, 2004. 
BATISTA, C. A. M. A prática da responsabilidade social e a inclusão das pessoas portadoras de deficiências. In: Encontro Nacional da ANPAD - EnANPAD, XXVII, Anais ..., Atibaia/SP, 2003, 1 CD ROM.

CAELLI, K.; RAY, L., MILL, J. 'Clear as mud': Toward greater clarity in generic qualitative research. International Journal of Qualitative Methods, 2003. Article 1. Retrieved. Disponível em: http://www.ualberta.ca/ iiqm/backissues/2_2/html/caellietal.htm Acesso em: 08 jun. 2006.

CARVALHO-FREITAS, M.N.; MARQUES A.L. Construção e validação de instrumentos de avaliação da gestão da diversidade: a inserção no trabalho de pessoas com deficiência. EnANPAD, 2006.

CHEETHAM, G; CHIVERS, G. Towards a holistic model of professional competence. Journal pf European Industrial Training, v. 20, n. 5. 1996.

Professions, competence and informal learning. Edward Elgar Chelteham - United Kingdon e Massachusets, USA. 2005.

COX Jr. T; BAELE, R.L. Developing competency to manage diversity: readings, cases and activities. San Francisco: Berret-Koehler Publishers, 1997.

DASS, P.; PARKER, B. Strategies for managing human resource diversity: from resistance to learning. Academy of Management Executive, v.13, n. 2, 1999.

DAVEL, E.; VERGARA, S. C. Gestão com pessoas e subjetividade. Gestão com pessoas, subjetividade, objetividade nas organizações, São Paulo: Atlas, 2001.

DOVAL, J. L. M.; HARO, D. G. Ingenuidade e exclusão: pessoas portadoras de deficiência no mercado competitivo. In: Encontro de Estudos Organizacionais da ANPAD - IV, EnEO, , Anais ..., Porto Alegre/RS, 2006, 1 CD ROM. 
FINEMAN, S. A emoção no processo de organizar; 1996. In: CLEGG, S.R.; HARDY, C.; NORD, W.R. Handbook de estudos organizacionais. v. 2; São Paulo: Atlas, 2001.

FRIEDMAN, V.; LIPSHITZ, R; OVERMEER, W. Creating Conditions for organizational Learning. In: DIERKES, M. et al. Organizational Learning \& Knowledge, New York: Oxford, 2001.

GEPHART, R. From the editors: qualitative research and the Academy of Management Journal. Academy of Management Journal, v. 47, n. 4, 2004.

GHERARDI, S. et al, F. Toward a social understanding of how people learn in organizations. Management Learning, v. 29, n. 3, 1998.

GIL FLORES, J. Analisis de datos cualitativos. Aplicaciones a la investigación educativa. Barcelona: PPU, 1994.

GOFFMAN, E. Estigma. Notas sobre a manipulação da identidade deteriorada. 4 $4^{\text {a }}$ ed. Tradução de Márcia Bandeira de Mello Leite Nunes. Rio de Janeiro: LTC, 1988.

HEINSKI, R. M .M. Um Estudo sobre a Inclusão da Pessoa Portadora de Deficiência no Mercado de Trabalho. In: Encontro Nacional da ANPAD - EnANPAD, XXVIII, Anais ..., Curitiba/PR, 2004, 1 CD ROM.

HUMAN, L. Managing workforce diversity: a critique and example from South Africa. International Journal of Manpower, v. 17, n. 4/5, 1996.

LE BOTERF, G. Desenvolvendo a competência dos profissionais. Tradução Patrícia Chittoni Ramos Reuillard. Porto Alegre: Artmed, 2003.

LEITE, I. C. B. V.; GODOY, A. S. ; ANTONELLO, C. S. . O aprendizado da função gerencial: os gerentes como atores e autores do seu processo de desenvolvimento. Aletheia (Canoas), v. 23, 2006.

MATVEEV, A. V.; MILTER, R. G. The value of multicultural competence for performance of multicultural teams. Team Performance Manager. v. 10, Issue 5-6, 2004. 
MERRIAM., S. B. Qualitative research and case study applications in Education. San Francisco: Jossey-Bass Publishers, 1998.

Qualitative research in practice: examples for discussion and analysis.

New York: Jossey-Bass, 2002.

MPOFU, E.; HARLEY, D.A. Racial and disability identity: implications for the career counseling of African Americans with disabilities. Rehabilitation Counseling Bulletin v. 50, n. 1, 2006.

PRESKILL, H.; TORRES, ROSALIE T. Papel do inquérito de avaliação na criação de organizações de aprendizagem, 1999. In: EASTERBY-SMITH, M; ARAUJO, L. \&

BURGOYNE, J. (Org..) Aprendizagem organizacional e organização de aprendizagem. SP, Atlas, 2001.

QUINTÃO, D. T. R. Algumas reflexões sobre a pessoa portadora de deficiência e sua relação com o social. Psicologia \& Sociedade, 17(1), Jan/Abr. 2005.

RAELIN, Joseph A.A Model of Worked-Based Learning. Organization Science: A Journal of the Institute of Management Sciences, Nov/Dec97, v. 8 n. 6, 2006.

SANDBERG, J. Understanding human competence at work: an interpretative approach. Academy of Management Journal. Briarcliff Manor: Feb . v. 43, n. 1, 2000.

SANDBERG, J. DALL'ALBA, G. Re-framing competence development at work. In: CASTLETON, G.; GERBER,R;PILLAY, H. Improving Workplace Learning: emerging international perspectives. Nova Science Publisher: New York, 2006.

SASSAKI, R.K. Inclusão. Construindo uma sociedade para todos. 7. ed. Rio de Janeiro: WVA, 2006.

SAWAIA,B. As artimanhas da exclusão: análise psicossocial e ética da desigualdade social. 5. ed. Petrópolis: Vozes, 2004. 
THOMAS, D.A.; ELY, Robin. Making differences matter. Harvard Business Review, sep.oct., 1996.

ZARIFIAN, P. Objetivo competência. São Paulo: Atlas, 2001.

\title{
RESUMO
}

Esta pesquisa teve como objetivo estudar a experiência de gestores na inclusão de pessoas com deficiência (PcDs) em suas equipes. A intenção foi identificar e analisar os processos de aprendizagem e as competências desenvolvidas pelos gestores para lidar com o universo da PcD, a partir dos modelos teóricos de Sandberg (2000), Cheetham e Chivers $(1996,2005)$ e Cox e Baele (1997). Seguindo os pressupostos do paradigma interpretativista e do estudo qualitativo básico (MERRIAM, 2002), foram analisadas as experiências de inclusão de seis gestores e seis PcDs a eles subordinadas, com deficiências moderadas a severas, em cinco empresas paulistas, multinacionais, dos segmentos editorial, energia, tecnologia diesel, agronegócios e automotivo. O principal instrumento de coleta de dados foi entrevistas em profundidade, complementadas por análise documental e observações diretas. A análise dos dados revelou que, para os gestores, o ato de incluir está mais relacionado à questão da justiça social do que à ideia de empoderamento da $\mathrm{PcD}$. Tal interpretação os levou a priorizar o desenvolvimento de dois tipos de competências: comportamentais e de éticas e valores. $\mathrm{O}$ principal processo de aprendizagem identificado para o desenvolvimento dessas competências foi o experiencial, o que levou os gestores a revisar seus conceitos, questionar e modificar suas crenças e, em consequência dessa reflexão, repensar sua forma de gerenciar. Os resultados pretendem contribuir para a discussão sobre o tema a partir de uma nova perspectiva: o gestor como agente de inclusão.

Palavras-chave: competências, diversidade, inclusão, pessoa com deficiência, gestores.

\section{THE DISABLED PERSON (DP) AND THE MANAGER: REFLECTIONS ON LEARNING AND COMPETENCIES IN THE CONSTRUCTION OF DIVERSITY IN ORGANIZATIONS.}

\begin{abstract}
This research aimed to study the experience of managers in the inclusion of persons with disabilities (DP) in their teams. The intention was to identify and analyze the processes of learning and skills developed by managers to deal with the universe of DP, based on theoretical models of Sandberg (2000), Cheetham and Chivers (1996, 2005) and Cox and Baele (1997). Following the assumptions of the interpretative paradigm and of the basic qualitative study (MERRIAM, 2002), we analyzed the experience of including six managers and six DP under their direction, with moderate to severe disabilities in five firms in Sao Paulo, multinational ones, from the segments of publishing, energy, diesel technology, automotive and agribusiness. The main instrument for data collection was in-depth interviews, supplemented by documentary analysis and direct observations. Data analysis revealed that, for the managers, the act of including is more related to social justice issues
\end{abstract}


than the idea of DP empowerment. Such interpretation led them to prioritize the development of two types of skills: behavioral and ethics and values. The main learning process identified for developing these skills was the experiential, which led the managers to revise their concepts, interrogate and modify their beliefs and, as a result of this reflection, revise their way of managing. The results are intended to contribute to the discussion on the topic from a new perspective: the manager as agent of inclusion.

Keywords: skills, diversity, inclusion, disabled people, managers. 